NBER WORKING PAPER SERIES

\title{
RESOLVING THE AFRICAN FINANCIAL DEVELOPMENT GAP: CROSS-COUNTRY COMPARISONS AND A WITHIN-COUNTRY STUDY OF KENYA
}

\author{
Franklin Allen \\ Elena Carletti \\ Robert Cull \\ Jun Qian \\ Lemma Senbet \\ Patricio Valenzuela \\ Working Paper 18013 \\ http://www.nber.org/papers/w18013
NATIONAL BUREAU OF ECONOMIC RESEARCH
1050 Massachusetts Avenue
Cambridge, MA 02138
April 2012

\begin{abstract}
We thank the Financial Sector Deepening Trust Kenya (FSD Kenya), and in particular David Ferrand, for providing the household surveys, and Samuel Makome and John Staley for providing information on Equity Bank. We appreciate helpful comments from Patrick Alila, Meghana Ayyagari, Thorsten Beck, Shawn Cole, Sankar De, Marcella Lucchetta, Randall Morck, Chukwuemeka Okoye, Daniel Sarpong, Moses Sichei, Philip Strahan, and seminar/session participants at Harvard Business School, Wesleyan University, the ERD Workshop in Accra, the Financial Intermediation Research Society meetings in Prague, the NBER African Successes 2011 conference in Zanzibar, and the Summer Research Conference at the Indian School of Business. We are grateful to Giulia La Mattina, Sailu Li, and Mircea Trandafir for excellent research assistance, and NBER and the authors' respective institutions for financial support. We are responsible for all the remaining errors. The views expressed herein are those of the authors and do not necessarily reflect the views of the National Bureau of Economic Research.
\end{abstract}

NBER working papers are circulated for discussion and comment purposes. They have not been peerreviewed or been subject to the review by the NBER Board of Directors that accompanies official NBER publications.

(C) 2012 by Franklin Allen, Elena Carletti, Robert Cull, Jun Qian, Lemma Senbet, and Patricio Valenzuela. All rights reserved. Short sections of text, not to exceed two paragraphs, may be quoted without explicit permission provided that full credit, including $(\mathcal{C}$ notice, is given to the source. 
Resolving the African Financial Development Gap: Cross-Country Comparisons and a Within-Country Study of Kenya

Franklin Allen, Elena Carletti, Robert Cull, Jun Qian, Lemma Senbet, and Patricio Valenzuela NBER Working Paper No. 18013

April 2012

JEL No. G0,K0,O5

\begin{abstract}
$\underline{\text { ABSTRACT }}$
With extensive country- and firm-level data sets we first document that the financial sectors of most sub-Saharan African countries remain significantly underdeveloped by the standards of other developing countries. We also find that population density appears to be considerably more important for banking sector development in Africa than elsewhere. To better understand how countries can overcome the high costs of developing viable banking sectors outside large metropolitan areas, we focus on Kenya, which has made significant strides in financial inclusion and development in recent years. We find a positive and significant impact of Equity Bank, a leading private commercial bank on financial access, especially for under-privileged households. Equity Bank's business model—providing financial services to population segments typically ignored by traditional commercial banks and generating sustainable profits in the process - can be a potential solution to the financial access problem that has hindered the development of inclusive financial sectors in many other African countries.
\end{abstract}

Franklin Allen

Wharton Finance Dept.

University of Pennsylvania

3620 Locust Walk

Philadelphia, PA 19104

and NBER

allenf@wharton.upenn.edu

Elena Carletti

European University Institute

Elena.Carletti@EUI.eu

Robert Cull

World Bank

rcull@worldbank.org
Jun Qian

Boston College

140 Commonwealth Ave

Chestnut Hill, MA 02467

qianju@bc.edu

Lemma Senbet

University of Maryland

Robert H Smith School of Business

College Park, MD 20742

1senbet@rhsmith.umd.edu

Patricio Valenzuela

European University Institute

patricio.valenzuela@eui.eu 


\section{Introduction}

Africa’s growth performance has long been disappointing and it has been described as a tragedy by some commentators (e.g., Easterly and Levine, 1997). Although less well-documented and perhaps not surprising, the financial sectors of sub-Saharan African countries remain woefully under-developed, even relative to the standards of developing countries. This is despite the fact that most of these countries have undergone extensive financial sector reforms in the last two decades of the same proportions as other developing and emerging countries. ${ }^{1}$

The financial development gap in sub-Saharan Africa is stark, and the gap is visible in the data. For example, the population-weighted trends for developing regions in terms of liquid liabilities and private credit (both divided by GDP) show that the rest of the developing world has seen substantial improvement relative to Africa in the last two decades, though the patterns differ across regions. Based on the pre-crisis data, the liquid liabilities of African financial sectors averaged below 30 percent of GDP in 2007 (see Table 1). In no other region of the developing world did that figure stand below 40 percent. The credit side of the picture looked even worse: private credit averaged 17 percent of GDP in Africa in 2007, compared with ratios ranging from 33 to 44 percent for other developing regions. These pre-crisis data show that the financial development indicators of Africa improved in the period 1995-2005, but at a much slower pace than in other developing and emerging countries in Asia, Eastern Europe, Latin America, and the Middle East.

The poor state of African financial development raises a number of important questions as to what went wrong with the financial reforms in Africa and what could be improved. Is African financial development slow in itself, or is it a reflection of broader economic and policy failures?

\footnotetext{
${ }^{1}$ The reform packages included price and interest rate liberalization, removal of credit ceilings, introduction of a variety of measures for banking and capital market development, including financial regulatory schemes, and large scale privatizations of state-owned enterprises (see, for instance, Nissanke and Aryeetey, 1998; Senbet and Otchere, 2006; and Honohan and Beck, 2007).
} 
Are the levels of financial development achieved in the developing world outside of Africa achievable for most African countries? What factors have inhibited African financial development to this point and how can they be overcome? Understanding these issues is of crucial importance given the ample empirical evidence of a linkage between financial development and economic development. $^{2}$ Moreover, in the context of Africa where poverty is so widespread, the positive finance-growth nexus is suggestive of a positive linkage between finance and poverty alleviation. ${ }^{3}$

There is very little rigorous academic research that addresses these questions. This paper represents a first step in addressing key issues at the heart of African financial development. We have three goals. First, we assess whether African financial development is slower than it ought to be, using other developing countries as a benchmark. Second, we identify factors that have more pronounced impact on financial development in Africa than in other developing countries, using both country- and firm-level data sets. The problem for banks, that try to increase financial inclusion, is whether they can generate sufficient profits to sustain their business model. In this regard, our third goal is to study Kenya, a country that has made significant strides in financial development in recent years, and Equity Bank, a leading private commercial bank devoted to providing banking services to lower income people. We examine the impact of Equity Bank, along with other commercial banks, on financial access at the household level in Kenya.

To calibrate the financial development 'gap' between Africa and other developing countries, we first analyze the determinants of financial development in other developing countries (low- and middle-income countries) via regression models based on prior research. ${ }^{4}$ We use the regression coefficients to generate predicted levels of financial development, as measured by the ratios of

\footnotetext{
2 See, for example, Levine (2005), Levine, Loayza, and Beck (2000), and Rajan and Zingales (1998).

${ }^{3}$ Recent cross-country studies also find links between financial development and (lower) incidence of poverty (Beck, Demirguc-Kunt, and Levine, 2007; Clarke, Xu, and Zou, 2006).

${ }^{4}$ Our main financial development variables cover the period 1995-2007. The negative impact of the 2007-2009 global financial crisis has been less severe in Africa than in other regions, in part because the financial sectors were more isolated from global markets. See, for instance, Kamil and Rai (2010) for more details.
} 
liquid liabilities and private credit over GDP, for sub-Saharan African countries (excluding South Africa). Then we compare those predicted levels with the actual levels of financial development in the African countries. We find that most African countries tend to have lower levels of financial development than would be predicted based on their fundamentals. The average country falls 13 percentage points short of its predicted level for liquid liabilities over GDP and 12 percentage points for private credit over GDP.

To identify common and unique factors associated with financial development (or lack of) in Africa, we run regressions for other developing countries and African countries separately; we also examine the combined sample with an African dummy, and interact the African dummy with factors affecting financial sector development. One of our main findings is that population density appears to be more important for banking sector development as measured by liquid liabilities and private credit (relative to GDP) in Africa than in other developing countries. If frequent interactions among firms, households, and investors are a necessary condition for business transactions, and hence financial development, then our results are plausible in that many African countries are endowed with scattered population and roads. Furthermore, we find a nonlinear relationship between population density and banking sector development, and the largest gap between Africa and the rest of the developing world is for those African countries 'trapped' in low density areas.

We further explore the channels through which population density may affect banking sector development by examining additional variables related to population density. We find that the percentage of population living in the largest cities, roads per square kilometer and bank branch penetration are all associated with a higher level of liquid liabilities relative to GDP, but the results are weaker for the level of private (bank) credit. These results imply that the minimum viable banking sector scale is best achieved in major cities, and that technological advances, such as mobile telephone banking, could be one way to facilitate African financial development, especially 
on the savings side of the banking sector outside metropolitan areas. ${ }^{5}$

Concerning other factors explaining banking sector development, we find that macroeconomic stability and broad measures of institutional quality are less important in Africa than in other developing countries, while the natural resource 'curse' (as in, e.g., Sachs and Warner, 1995, 2001) is no worse in Africa than elsewhere. Finally, regarding indicators of stock market development, such as market capitalization and turnover, we do not find any of the factors associated with stock market development in the rest of the world to be significant in Africa. In large part, this is because most African stock markets remain thin, illiquid and dysfunctional; and only very recently have Sub-Saharan African countries made a policy commitment to their development.

We also conduct firm-level analyses which enable us to control for both country-level variables and firm characteristics in the same regressions. Employing the widely used World Bank global Investment Climate Surveys (ICS), which are comprised primarily of firms that are not listed on stock markets, we examine factors determining firms' access to external finance in the form of bank loans (from both domestic and foreign banks) and/or credit cards. ${ }^{6}$ The idea is that if a country’s banking sector is more developed, firms, and in particular privately owned firms, should have easier access to these types of formal finance. We run regression models where we include the same country-level factors as in our cross-country studies as well as firm characteristics that could explain substantial variations in the demand for and in the use of financial services. Once again, we include the African dummy and interact it with both country-level and firm-level variables.

The results of the micro-level regressions confirm that population density is an important

\footnotetext{
${ }^{5}$ Mbiti and Weil (2010) use the same household surveys in Kenya as in our paper, and find that increased use of MPesa, one of the leading mobile phone based money transfer systems, lowers the propensity of people to use informal savings mechanisms but raises the probability of their use of banking services.

${ }^{6}$ This is consistent with prior research showing that financial institutions provide the most important source of external finance in most developing countries (e.g., Beck, Demirgüç-Kunt, and Levine 2000).
} 
factor for access of firms to financial institutions. While bank branch penetration is an important factor for access to bank finance, the coverage of roads is not as important for African firms as their counterparts elsewhere. As with country-level studies, general infrastructural failures are not necessarily responsible for low levels of firm access to bank finance in Africa, but rather failures are specific to the banking sector and markets for loans. While manufacturers are more likely to access bank finance in other countries, they show no strong tendency to rely on external finance relative to other firms in Africa.

Having established population density as a key factor for financial development in Africa based on both cross-country and firm-level data, we next conduct a within-country study on Kenya. There are several reasons for this choice. First, based on our cross-country analysis, Kenya's level of financial development is not too far off from the predicted level, and it has witnessed a strong bank branch expansion in recent years. This expansion has also coincided with the emergence of Equity Bank, a pioneering (for-profit) commercial bank that devised a banking service strategy targeting low income clients and traditionally under-served territories. The bank is listed on the Nairobi Stock Exchange, and has no government ownership share. Many scholars and policy makers agree that a key obstacle to financial development is access of the disadvantaged to finance, which would promote economic growth at the broadest scales. While the success of microfinance institutions (MFIs), such as Grameen Bank, has captured the attention of economists and policy makers, many MFIs currently are beset by non-repayment problems while most established commercial banks view the sectors targeted by MFIs as 'unbankable.' This makes Equity Bank and Kenya a particularly interesting ‘laboratory’ for the study of financial access. Since institutional and macroeconomic conditions tend to be more homogeneous within a single country, the findings from our within-country study can reinforce the results from our cross-country study.

The absence of micro-level data at both the household and bank branch level has made the 
study of financial inclusion a challenge. Fortunately, we are able to overcome that challenge using a new dataset on bank branch penetration at the district-level described in Allen et al. (2011), matched with household surveys of financial usage for Kenya that were conducted in 2006 and 2009. We find that Equity Bank presence is strongly associated with increases in households' usage of bank accounts and bank credit between the two surveys. These effects are particularly strong for under privileged households — those with low income and less education, who do not own a permanent house, and those that lack any member with a salaried job.

We also find differences in branching strategies between Equity Bank and other commercial banks. While all bank types (including Equity Bank) open a greater number of branches in urban, highly populated and English speaking districts, Equity Bank was more likely to expand to underdeveloped districts than other types of banks between 2006 and 2009— less densely populated areas and areas where the dominant language was not English or Swahili. This different branching strategy is consistent with our earlier result that population density is a major obstacle for financial sector development in Africa; more importantly, our results are encouraging in the sense that private institutions can arise in such an environment to help overcome the 'no finance, no growth trap' in many African countries.

The rest of the paper is organized as follows. Section II describes the data, methodology for benchmarking financial development across countries, and results on examining whether the actual financial sector development in Africa is below what the fundamentals would predict using other developing countries as benchmarks. Then Section III examines whether the variables associated with banking development in other developing countries from our base models are related in a similar way to African banking development. Section IV presents results on the determinants of firm access to external finance in Africa and other developing countries. Section V presents results on financial access in Kenya and on the effect of bank branch expansion, particularly Equity Bank 
branching strategy on the use of bank accounts and credit. Section VI offers concluding remarks.

\section{Benchmarking Financial Development}

For cross-country comparison of financial development, the literature has turned increasingly to regression analysis to examine the level and variation of financial development across countries relying on some of the same variables that have been used to study the links between financial development and growth (Levine, 2005). ${ }^{7}$ There is no general consensus in the literature about the factors that should be taken into account in explaining financial development, nor what indicators of that development are most reliable. In the choice of the latter, we ground our analyses on the recent attempt by Beck et al. (2008) to standardize the selection of financial development indicators. Under this approach, the potential financial development indicators are ranked on the basis of the following criteria: (a) the directness of their linkages to welfare, (b) the goodness of fit of regressions that explain variations in them, (c) their coverage in terms of countries and years, and, (d) the degree to which an indicator is stable within a country from year to year, but varies substantially across countries. ${ }^{8}$

In most of our analysis we use the two standard indicators, namely the ratio of liquid liabilities in the banking system to GDP and the ratio of credit to private sector to GDP. Both measures score among the highest based on all four criteria listed above. They score especially high relative to others on the first criterion, because they are robustly associated with long-run economic growth (Levine 2005; Levine, Loayza, and Beck, 2000). Moreover, our analysis is rooted in banking indicators because banks hold the vast majority of financial sector assets in Africa and

\footnotetext{
${ }^{7}$ As in other recent papers, we use these variables, including growth, to describe financial development (Cull and Effron, 2008; Cull, Senbet, and Sorge, 2005). By contrast, in the finance and growth literature, the financial indicators are among the explanatory variables used to explain growth.

${ }^{8}$ Beck et al. (2008) call this the ratio of within sample variance to between sample variance. They worry that high within-country variation may reflect measurement errors or a high degree of co-movement with the business cycle. They argue that indicators of financial development are (or at least should be) better suited to measuring longer-term differences across countries rather than fluctuations along the cycle for a given country.
} 
other developing countries. ${ }^{9}$ Despite this, we perform some robustness checks using measures of stock market development as indicators of financial development.

In the choice of the explanatory variables for financial development, we rely again on previous studies, in particular those on the finance-growth nexus (e.g., Levine, 2005) and from other studies that analyze the determinants of financial development (e.g., Beck et. al, 2008; Cull and Effron, 2008). These studies (in particular, Beck et al. 2008) regress the indicators of financial development on a set of variables that describe the environment in which such development takes place, but that are exogenous to that process such as population size and density, natural resources and offshore centers. They also include per capita income as an exogenous regressor, claiming that its effect on financial development is contemporaneous while the effect of financial development on income is lagged. The residuals from those regressions, therefore, provide an indication of the extent to which the chosen government policies promote financial development.

However, as our objective is to benchmark African financial development relative to a set of variables that have been robustly associated with financial development in countries outside of Africa, especially in low and middle income countries, we expand further the set of regressors by including macroeconomic variables, such as inflation, real growth, and the current account balance, broad measures of institutional development, and variables describing banking sector structure. We stress from the outset that we are not necessarily estimating causal relationships for the expanded set of regressors. For ease of exposition, however, we refer to all explanatory variables as determinants of financial development throughout the paper.

\footnotetext{
${ }^{9}$ The ratio of private credit to GDP can include lending by nonbank financial institutions. As Table 2 shows, though, the correlations between private credit/GDP and stock market capitalization, and those between liquid liabilities/GDP and stock market capitalization/GDP are of similar magnitude (0.65 and 0.68), suggesting that the private credit measure is not driven by the activities of nonbank financial institutions involved in stock market transactions.
} 


\section{II.1 Regression Model}

We begin the introduction of our regression model with the dependent variable:

Financial Development indicator $\left(F D_{i}\right)$ : This measures an indicator of financial

development in country $i$. We average our indicators of financial development and our explanatory variables over multiple years (from 2001 to 2005), as is customary in the literature on financial development and growth so as to reduce the influence of outliers. We therefore have only one observation per country. The results are qualitatively similar when we use all yearly observations from 1990 to 2006 in panel regressions, and when we lag the explanatory variables in either the panel regressions or the cross-sectional regressions. Because our goal is to describe a general picture of the factors that are robustly linked to financial development, however, we present below only the simplest cross-country regressions in which the financial indicators and explanatory variables are contemporaneous. ${ }^{10}$

The regression model for the expanded set of explanatory variables is:

\begin{tabular}{|c|c|}
\hline (1) $\begin{aligned} F D_{i}= & \alpha+\beta_{1} \text { Population }_{i} \\
& +\beta_{2} \text { Population Density }_{i} \\
& +\beta_{3} \text { Natural Resources }_{i} \\
& +\beta_{4} \text { Offshore Center }_{i}\end{aligned}$ & $\begin{array}{l}\text { Exogenous determinants, based on Beck et al. } \\
\text { (2008) }\end{array}$ \\
\hline $\begin{array}{l}+\beta_{5} \text { Per Capita Income } \\
+\beta_{6} \text { Population } * G D P \text { Per Capita }_{i}\end{array}$ & $\begin{array}{l}\text { Plausibly exogenous, Financial development } \\
\text { affects these variables at a lag, Beck et al. (2008) }\end{array}$ \\
\hline $\begin{array}{l}+\beta_{7} \text { Real GDP Growth Rate }_{i} \\
+\beta_{8} \text { Inflation Rate } \\
+\beta_{9} \text { Current Account Balance } / G D P_{i}\end{array}$ & Macroeconomic variables \\
\hline$+B_{10} K K M$ Index $_{i}$ & Index of institutional development \\
\hline $\begin{array}{l}+B_{11}{\text { Manufacturing } / G D P_{i}} \\
+B_{12} \text { Secondary/Primary enrolment } \\
+\varepsilon_{i}\end{array}$ & Other variables \\
\hline
\end{tabular}

We briefly explain our variables below:

\footnotetext{
${ }^{10}$ For example, in the cross-sectional regression we average the explanatory variables from 1990 to 2000 and use them to explain financial development indicators averaged from 2001 to 2005 . In the panel regression, we lag the explanatory variables by one to three years.
} 


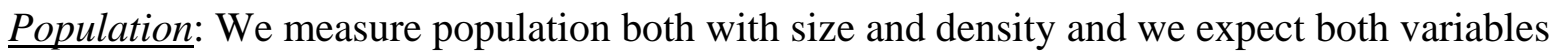
to be positively associated with financial development. A larger population should spur financial development due to scale and networking effects that make provision of financial services more efficient in larger economies. Population density, as measured by the number of residents per square kilometre, should have a positive coefficient in part because it is easier for financial institutions to accumulate savings when a higher number of potential depositors have easy access to them.

Natural Resources: An abundance of natural resources may have a negative effect on financial development via the so-called "resource curse." Consistent with this, Sachs and Warner (1995, 2001) offer evidence that resource-rich developing countries have grown more slowly since 1960 than other developing countries.

We measure the intensity of a country's reliance on natural resources by using a comprehensive approach that measures resource abundance based on trade indicators rather than solely on oil exports:

Natural resources $=\sum_{k} \frac{\text { Exports }_{k}-\text { Imports }_{k}}{\text { Population ages15-64 }}$, where $k \in\left\{\begin{array}{c}\text { petroleum,forest, tropical, } \\ \text { animal,cereal,raw materials }\end{array}\right\}$

The key advantage of this approach is that this measure of net exports is available for most countries and, as shown by Lederman and Maloney (2008), it is more closely linked to actual natural resource reserves than other trade-based endowment measures. If there is a resource curse and it impacts financial development, we would expect the coefficient on this variable to be negative.

Offshore Centers: The financial sectors of offshore centers are typically much larger than their economies would otherwise warrant. We measure this effect with a dummy variable for offshore financial centers and we expect it to be positive. ${ }^{11}$

\footnotetext{
${ }^{11}$ One could question whether this is an exogenous variable. We follow Beck et al. (2008) in taking it as exogenous.
} 
Per Capita Income: Per capita income is expected to be positively linked to financial development, because the volume and the sophistication of financial activities demanded is greater in richer countries and, on the supply side, richer economies can better exploit scale economies in the provision of financial services. Per capita income reflects an aggregation of past growth, and hence its coefficient summarizes the long-run positive relationship between growth and financial development. Moreover, per capita income may interact with population to produce even greater financial development than they do individually. We test this by including the interaction between those two variables in the regression.

Indicators of Macroeconomic Stability: Financial development is more likely in a sound macroeconomic environment and to measure this, we include real growth, inflation and the current account balance (relative to GDP) in the regressions.

(a) Real growth: The effect of real growth on financial development is ambiguous. On the one hand, countries with rapid growth may be associated with greater financial development. On the other hand, countries with higher levels of development, as reflected in GDP per capita, tend to have slower growth according to ‘conditional convergence’ (Levine and Renelt, 1992; Easterly and Levine, 1997). Given that financial development indicators tend to be highly correlated with per capita income, it is likely that the faster growing countries will also tend to have lower levels of financial development. We would therefore expect a negative coefficient for real growth in our financial development regressions. The coefficient should also capture the negative short-run relationship between financial development and growth as emphasized in Loayza and Ranciere (2006).

(b) Inflation: On the private credit side, inflation should slow financial development if it makes loan contracting over extended periods more difficult. Inflation could also have a dampening effect on liquid liabilities, making depositors more hesitant to place their savings in the formal 
financial system for fear of not being able to get them back quickly enough. Therefore, we expect the coefficient for inflation to be negative in our regressions.

(c) Current Account Balance: The current account balance can be seen as a rough indicator of the health of the macroeconomic environment, and we thus expect it to be positively associated with our financial indicators.

Institutional Development: We include in the regression KKM, which is the measure of broad institutional development created by Kaufmann, Kraay, and Maztruzzi (2007). Institutional development has been found to foster financial development in developing countries (Cull and Effron, 2008), and thus we expect a positive coefficient for KKM in our regressions.

Manufacturing: We include the share of GDP generated by the manufacturing sector. Industrial sectors that are relatively more in need of finance tend to grow faster in countries with well-developed financial sectors (Rajan and Zingales, 1998). Manufacturing encompasses a broad variety of activities that tend to rely heavily on external finance so that we expect countries with a large manufacturing sector to have well-developed complementary financial institutions. We therefore expect a positive coefficient for manufacturing in our regressions.

Secondary/Primary enrollment: Finally, we want to measure the impact of risk management on financial development. The idea is that a lack of capacity in risk management may be a deterrent to banking sector development and broader financial sector development (e.g., stock markets). As measuring financial capabilities across countries directly is not possible, we proxy risk management capability with the ratio of secondary to primary school enrolment and we expect its coefficient to be positive. Our argument is that risk management capability is fundamentally a question of human capital development and thus of talented financial people.

The summary statistics and the correlations between the key variables appear in Tables 1 and 2. Table 1 shows that the mean values for the financial indicators are uniformly lower in Africa 
than the rest of the world, measured in terms of liquid liabilities, private credit provision, and stock market development. We also see marked differences in the explanatory variables between Africa and the rest of the world, particularly with respect to population density, per capita income, current account balance/GDP and institutional development as proxied by the KKM index.

The correlations in Table 2 are instructive. All indicators of financial development -liquid liabilities/GDP, private credit/GDP, stock market capitalization/GDP, and stock market value traded/GDP- are highly correlated; and population density is positively associated with two of them, liquid liabilities/GDP and stock market capitalization/GDP. The macro economic variables are strongly associated with the measures of financial development in an expected way. In particular, there is a negative relationship between the financial development indicators and both inflation and real growth, and a positive relationship between the indicators and the current account balance. However, the relationship with real growth is weaker than the other macro variables. The KKM index of institutional development is strongly and positively associated with all of the indicators of financial development. The same holds for the log of per capita income. This is indicative of a positive long-run relationship between finance and growth. Finally, the secondary/primary school enrollment is positively associated with the measures of financial development

\section{II.2 Empirical Results at Cross-Country Level: The African Financial Development Gap}

To benchmark African financial development, we estimate regression Equation (1) for countries outside Africa, which enables us predict what African financial development should be based on the experience of these other countries. Specifically, we first run the regressions excluding all African countries, and we derive out-of-sample predictions for African financial development. Then we compare these predictions with the actual levels of African financial 
development to measure the development gap. ${ }^{12}$ We present models for all countries and for low and middle income countries separately in Table 3. The latter are more reflective of the African experience.

\section{A. Benchmarking Results for the Determinants of Financial Development}

The results for regression Equation (1) are presented in Table 3. The signs of almost all of the coefficients are as predicted and many of them are significant. When we use the full sample of countries and the limited set of regressors as a benchmark, (see Columns 1 and 5), only the Per Capita Income Variable is positively associated with both indicators of banking development, while our proxy for Natural Resource intensity is negatively linked to those indicators. Population Density and Offshore Financial Center are significantly positive in the liquid liabilities regression (Column 1) but not the private credit regression (Column 5). When we benchmark to a sample of only low and middle income countries, using the limited set of regressors (Columns 3 and 7), the Offshore Financial Center is highly significant for both indicators, while the Per Capita Income and Population Density variables are positive and significant, but only in the private credit regression. ${ }^{13}$ The expanded regression results, where we include macroeconomic, institutional, and other explanatory variables, are presented in Columns 2, 4, 6 and 8. The results show that Real Growth is negative and significant (or very nearly so) for both private credit and liquid liabilities for both samples of countries that we use. This indicates that the fastest growing countries tend to have the

\footnotetext{
${ }^{12}$ The same approach has been used, for example, to assess whether the levels of foreign direct investment received by China are abnormally high, or whether they can be explained by fundamentals (Fan, Morck, Xu, and Yeung, 2008).

${ }^{13}$ These results are similar to those in Beck et al., (2008). Aside from our proxy for natural resource intensity, our regressions differ from theirs in two ways. First, we use the more conservative cross-sectional approach, whereas they use the full panel. We choose to do this because errors from observations from the same country are likely to be correlated with one another. This could artificially deflate standard errors, thus increasing the significance level of coefficients. For robustness, we ran our models also on the full panel and qualitative results are similar. Second, they include a poverty gap variable in their regressions, which is the proportion of the population under the poverty line, times the average distance from the poverty line (Source: Povcal Net, World Bank). Since the poverty gap is so tightly linked to income levels, they use the residuals from a regression of the poverty gap on income in their regressions. We did the same, but the variable provided little explanatory power and reduced our sample. Also, unlike the other variables in our analysis, the poverty counts are based on surveys that do not occur at regular intervals, and thus the panel is highly unbalanced. For these reasons, we present models without the poverty gap variable.
} 
least-developed financial sectors, providing support for conditional convergence. As discussed earlier, this is likely a reflection of a short-run relationship between financial development and growth (the positive significant coefficient for per capita income summarizes the long run relationship between accumulated growth and financial development). Inflation is negative and highly significant across financial indicators and country samples. The coefficients are similar in size for the full set of countries and for the low and middle income countries, indicating that macroeconomic instability is strongly linked to financial under-development even in developing countries. The Current Account Balance/GDP is strongly positively linked to both indicators for both samples, though coefficients are larger for the low and middle income sample. In short, the coefficients support our hypotheses and indicate strong links between macroeconomic outcomes and financial development.

Our proxy for the degree of institutional development, as represented by the KKM index, is positive and highly significant across financial indicators and samples, providing support for the notion that broad institutional development helps to foster financial development. The coefficients are larger for the full-country sample than for the sample of low and middle income countries, but they are still large even in the latter case: a one-point increase in the KKM index (5-point scale) is associated with a 22 percentage point increase in liquid liabilities/GDP and a 21 percentage point increase for the private credit ratio. Finally, in the expanded models, the offshore financial center variable is significant for both indicators for low and middle income countries.

\section{B. Predicted Versus Actual African Financial Development}

We now use the regression coefficients in Table 3 to derive a predicted level of financial development for each country in Africa. Because they are likely to be more reflective of the African experience, as our benchmark we rely on the models that include only low and middle income 
countries. ${ }^{14}$ Again, we are not claiming that the relationships we find in Table 3 are causal. Rather, we are asking what the level of financial development would be if the same relationships held in Africa as in the rest of the developing world. To the extent that predicted and actual levels of financial development are similar, one can say that African financial development is about what it should be.

1. African financial development gap: Liquid liabilities. Figure 1shows that only seven of thirtyone countries have levels of liquid liabilities/GDP which are at or above their predicted levels. Of those, three (Angola, Sierra Leone, and Zambia) are huddled in the lower left hand corner of the figure where actual and predicted values are very low. Because the predicted values are based on linear regressions, they tend to be very near zero for these countries. ${ }^{15}$ That their actual levels exceed zero by some small amount is little consolation. To a lesser extent the same is true of Mozambique. Ethiopia has predicted and actual levels of liquid liabilities that are quite similar. The result on Ethiopia seems surprising given the country is known to have undertaken few financial sector reforms and has a banking system dominated by the government. While stateowned banks collect deposits, it unlikely that they intermediate (lend) well. In fact, the dominant bank in Ethiopia was known to have a high accumulation of liquidity and idle funds during the sample period, and the relatively high level of liquid liabilities (relative to GDP) may be reflective of excess liquidity. Overall, there are only two countries, namely Cape Verde and Mauritius among the smallest in Africa - that exceed their predicted levels by a substantial amount, but neither of the two is particularly reflective of the African experience.

As Figure 1 shows, twenty countries have levels of liquid liabilities that are more than ten

\footnotetext{
${ }^{14}$ We also tried to estimate models based only on low income countries outside of Africa, but there were too few observations to generate meaningful results.

${ }^{15}$ Indeed, for Angola the predicted value is negative (and large in absolute value). This is due to its high average GDP growth (10.6\%), low KKM score (-.71), and high inflation (86.4\% per year). Negative levels of financial development are not, however, possible. For countries that have negative predicted values, we reset them to zero in both the figures. The calculations are discussed in the text.
} 
percentage points below their predicted levels. The worst ten performers, for example, range between 24 and 47 percentage points below. The average country falls 13 percentage points short of its predicted level, which is quite sizable, given that the average ratio of liquid liabilities to GDP hovered between 26.5 and 30.9\% from 2001 to 2005 .

2. African financial development gap: Private Credit: As shown in Figure 2, the level of private credit/GDP for African countries lies far below predicted levels. Again, only seven countries exceed their predicted levels and only Mauritius does so by more than ten percentage points. Of the twenty-four countries with predicted levels that are higher than their actual private credit ratios, seventeen fall short by more than ten percentage points. The ten poorest performers range from 22 to 34 percentage points below their predicted levels, and the average country falls short of its predicted level by 12 points. The magnitude of this measure of under-performance is quite large when one considers that the average ratio of private credit to GDP stood at 15.5\% in 2005.

The gap in the observed African financial development, relative to what is predicted by the benchmark determinants, is stark. The levels of liquid liabilities to GDP for African countries are about two-thirds the level predicted by statistical relationships that hold elsewhere in the developing world. Private credit ratios are even lower, slightly better than half their predicted levels. There is also general consistency in rankings across the two indicators. Of the bottom ten performers in terms of liquid liabilities, seven are also among the bottom performers in terms of private credit, and the correlation for the differences between predicted and actual levels for the two measures of financial development is 0.85 . Our results point to systematic under-performance relative to the fundamentals that have been associated with banking sector development in the rest of the world. To analyze this gap more in depth, in the next sections we look at whether the factors in our base models relate to African financial development differently than to financial development in the rest of the world. 


\section{Are the Determinants of African Financial Development Different?}

So far we have defined under-development in African financial sectors in terms of the determinants of financial sector development in other parts of the developing world. However, the course of African financial sector development might depend on a different set of factors than those that have been important elsewhere. ${ }^{16}$ While we are reluctant to accept that African financial sectors have a distinct model of development, it seems plausible that some factors may be somewhat more or less important in the African context. To see whether this is indeed the case, as a first step, we estimate the model in Table 4 for the sample of African countries. Note that this method essentially accepts that the level of financial development in Africa is lower than that in the rest of the developing world, and then tries to explain variation around the African mean based on the explanatory variables in our base models. Still, the results are instructive. ${ }^{17}$

First, population density is much more strongly linked to both liquid liabilities/GDP and private credit/GDP than it was elsewhere in the world. In fact, among the set of exogenous factors in the regression Equation (1), population density is the only one that is robustly linked to our indicators of banking development for Africa. Moreover, the interaction between population and per capita income is positive and significant in two of the private credit regressions, although not when South Africa is dropped from the African sample. This is reasonable, given the relatively high level of economic development of this country. Second, among the factors that explain financial development in the rest of the developing world, only the KKM index of institutional development seems relevant for Africa but only for the liquid liabilities measure.

The other additional factors in the expanded regressions in Table 4 are less important in Africa than elsewhere. Real growth is not significant. We argued earlier that the negative,

\footnotetext{
16 It may also be that the factors explaining financial development in Africa are the same as for the other countries but these factors load up or contribute differently in the African context. We are open to either interpretation.

${ }^{17}$ Note that the offshore financial center variable does not appear in Table 4 because no African countries qualify.
} 
significant coefficient for growth in the rest of the developing world was consistent with conditional convergence, because it indicated that the least financially developed countries had higher current growth rates. The non-result for Africa suggests that such convergence did not occur there, a point which was also made for some African countries in Pritchett (1997). In addition, neither inflation nor the current account balance is significant in the African regressions, whereas both were highly significant in the rest of the world as shown in Table 3. The poor results for inflation, the current account, and growth indicate that the macroeconomic fundamentals that are associated with financial development in other developing countries have not been important in Africa. ${ }^{18}$

\section{III.1. A Closer Look at Differences in Financial Development Factors}

The models in Table 4 provide a strong initial indication that the factors associated with banking development in Africa differ from those in the rest of the world. However, those African models are based on only a small number of observations. To address the small sample issue we rerun our models for all low and middle income countries (including Africa) and include an interaction between each of our explanatory variables and an Africa dummy variable. We also include an Africa dummy variable on its own to test whether the constant for Africa in our regressions is the same as in the rest of the developing world. This is akin to a seemingly unrelated regression (SUR), but the coefficients on the interactions terms enable us to make more precise statements about whether the effects for Africa are statistically different than for the rest of the developing world and from zero (i.e., there is no effect).

\footnotetext{
${ }^{18}$ The results on macroeconomic fundamentals suggest that African countries were able to avoid the financial rollercoaster ride associated with macroeconomic instability that other countries experienced during this period. However, this apparent benefit might have come at a substantial opportunity cost associated with the same low levels of financial development during this period. To some extent, therefore, our benchmark regressions used to predict African financial sector development give credit to some African countries for having relatively low initial levels of development, stable prices, and a current account surplus. These factors contribute to higher predicted financial development than has actually occurred.
} 
The results are presented in Table 5. In the simplest regressions, we include the Africa dummy and the limited set of regressors (Columns 1 and 4). The Africa dummy is negative for both indicators but it is significant only in the liquid liabilities regression. Per capita income is positive and significant for both indicators; and it remains positive when the Africa interactions are introduced (Columns 2 and 5), although it then becomes insignificant in the liquid liabilities regression. Moreover, per capita income is not significant when we introduce the African interaction terms for the expanded set of regressors (Columns 3 and 6). The offshore financial center variable is positive and significant across all specifications, though again no African country qualifies as an offshore center and so there is no Africa interaction for the variable.

The most relevant explanatory variable for Africa is again population density. When only the limited set of regressors is included in the regression, population density is positive and highly significant for both indicators of financial development (Columns 1 and 4). When the Africa dummy is interacted with the limited set of regressors (Columns 2 and 5), the relationship is still positive but weaker in terms of significance. When interactions are included for the expanded set of regressors (Columns 3 and 6), the variable remains positive but is no longer significant. Despite the insignificance of the density variable in models 3 and 6, we reject that the sum of the coefficients for density and its interaction with the Africa dummy is zero at the $p=0.1$ level for those models (see F-statistics near the bottom of Table 5). Therefore, the relationship between population density and our banking development indicators for African countries is significantly different from zero, but not for the rest of the developing world in our most expansive models.

In contrast, the relationship between natural resource intensity and banking indicators is about the same in Africa as it is in the rest of the developing world. The coefficient for our proxy of natural resource intensity is negative but tends not to be significant in most of the models; the coefficient for its interaction with the Africa dummy is never significant. Thus, we reject the 
hypothesis that the relationship between natural resources and banking development is somehow different for Africa. In other words, the relatively low levels of banking development cannot be attributable to the natural resource curse being more severe in Africa than in other parts of the developing world. Aside from the negative significant coefficient in model 3 (for liquid liabilities), the results provide little support for a resource curse in terms of financial development outside Africa as well.

Concerning the regressors that are only included in the expanded set, the coefficient for real growth is negative and highly significant for both indicators of financial development (Columns 3 and 6). The coefficient for the Africa*growth interaction is positive and insignificant; but, we cannot reject the hypothesis that the sum of the two coefficients (growth and Africa*growth) is zero (again see F-statistics near the bottom of Table 5). This indicates again that the conditional convergence result does not hold in Africa, as was suggested by our simple comparison of the coefficients from the base model (Table 3) with those from the African models (Table 4).

Similar results hold for the inflation variable which remains negative and highly significant when the interactions are included in the regressions. The interaction between inflation and the Africa dummy is positive, marginally significant, and of a magnitude similar to that of the simple inflation variable. We cannot, therefore, reject the hypothesis that the sum of the inflation and Africa*inflation variables is zero, which indicates that, like real growth, inflation also has not been associated with less financial development in Africa.

A similar pattern also holds for the current account balance and KKM index of institutional development variables. Both sets of coefficients are positive and significant in both specifications (Columns 3 and 6), but their signs are negative when interacted with the Africa dummy variable. We cannot reject the hypothesis that the sum of the two coefficients is equal to zero for both variables; that is, neither the current account balance nor KKM index is positively related to African 
banking development. The regressions that include interaction terms therefore indicate that the high predicted levels of financial development for Africa from our base models derive, in part, from macroeconomic factors that matter only outside Africa.

\section{B. Toward Resolving the African Finance Puzzle}

Are the determinants of financial development different in Africa? The more refined analysis in Table 5 indicates that the determinants of banking development in Africa differ from other developing countries in significant ways. Of particular interest is the set of factors that matter outside Africa but not in Africa, and those that matter in Africa but not in the rest of the world.

While macroeconomic variables and the KKM index of institutional development appear to be important determinants of banking development in the rest of the developing world, they lose power in the context of Africa. We also observe that the notion of a natural resource curse, which is largely popularized in the context of resource-rich countries such as those in Africa, is insignificant in explaining the African financial development gap. The one explanatory variable that stands out for Africa is population density. Our results show a steeper relationship between population density and banking indicators for Africa than the rest of the developing world.

In general, the differences between the predicted and actual values of financial development for Africa become smaller when the interaction terms are included in the regressions. In fact, the average difference for the models with full interactions is very close to zero. No difference is greater than 0.06 or less than -0.06 for either indicator of banking development. The majority of the predicted values lie within two percentage points of their actual levels. The simple Africa dummy, which is really a measure of our ignorance about what drives African financial development, tends not to be significant (and never achieves significance at better than the ten percent level).

Our findings suggest that, if mechanisms for holding down inflation, generating a current account surplus, and conditional convergence were to work in Africa as elsewhere, the levels of 
financial development would be higher. At the same time, it remains an open question as to why those mechanisms do not seem to work in Africa. Perhaps a period of sustained economic growth will ignite those mechanisms, but the African puzzle continues in a different form. ${ }^{19}$

\section{Additional Tests and Robustness Checks}

We now perform additional tests and robustness checks. In particular, we analyze in further depth the role of population density, which shows up more strongly in Africa than elsewhere. Moreover, we consider indicators of stock market development to test whether a gap similar to the one found for banking development indicators arises in the context of stock markets. Although stock markets still remain small and illiquid, African countries seem to have committed to the equity sector in promoting financial development and several stock exchanges have emerged in Africa in the recent past.

1. Population density: We try to better understand why sparsely populated African countries have low levels of banking development by, first, examining the 'shape' of the relationship between density and financial development based on our regression models and, second, including additional variables related to population density in the regressions.

Figure 3 shows the relationship between population density and liquid liabilities/GDP for the typical African and non-African developing country based on Table 5. Specifically, the vertical axis plots predicted values from Model 2 in Table 5. For all variables other than population density, we use the mean value for the subsample (either Africa or other developing countries) multiplied by the appropriate coefficient for that subsample. For population density, we run through the range of possible values and multiply by the appropriate coefficient for each subsample to generate the

\footnotetext{
${ }^{19}$ Another possibility is that variables that are important for African financial development are omitted from our models. For example, Easterly and Levine (1997) demonstrate that ethnic fractionalization explains a large share of factors that are linked to (slow) growth within Africa. We experimented with two types of variables: fractionalization and armed conflict. We use the fractionalization data as in Alesina et al. (2003); and we use the UCDP/PRIO dataset to calculate the average number of armed conflicts per year for each country. Neither variable is significant in our banking development regressions, and their inclusion does not alter the main qualitative results of our models.
} 
curvature. Hence, non-population density factors (partially) account for the distance between the curves for Africa and that for other developing countries.

Three features of the graph for liquid liabilities in Figure 3 are worth noting: (1) the largest differences between Africa and the rest of the developing world come at the lower end of the density scale; (2) population density affects financial development in all countries but the relationship is much steeper for Africa; and (3) although African countries tend to have lower population densities, there is substantial overlap for the two samples, which suggests that comparisons across the full range of the density spectrum are valid. The picture points to important differences between Africa and the rest of the world, which could be due to the fact that the minimum viable scale in banking is greater in Africa than elsewhere or to other institutional or infrastructural failures. Regardless of the explanation, Figure 3 highlights Africa’s difficulty in overcoming problems related to scale for the least densely populated countries.

Similarly to Figure 3, Figure 4 shows the relationship between population density and private credit/GDP based on the coefficients of Model 5 in Table 5. As in the figure for liquid liabilities/GDP, the gap between Africa and the rest of the developing world is largest at the lowest levels of population density. However, unlike for the liquid liabilities measure, that gap does not dramatically close at intermediate density levels. This suggests that while differences in minimum viable scale could explain differences between Africa and the rest of the developing world with respect to savings, they cannot account for Africa's lower levels of private credit over the full range of population densities.

To understand the aspects of population density that contribute to low levels of banking development in Africa, we include additional variables in our regressions that summarize (1) spatial population characteristics, such as large population agglomerations, (2) infrastructural and transportation development, and (3) physical banking presence (i.e., branch penetration measures). 
The results of these new regressions can help understand what policies may be effective in fostering African development. If population agglomeration and infrastructural development can account for most of the strong relationship between population density and banking under-development in Africa, provision of financial services might improve as a natural consequence of broader economic/infrastructural improvements or policies that specifically encourage economic participation by those that live outside urban agglomerates. On the other hand, if measures of bank branch penetration are better able to account for the density/banking development relationship in Africa, then it is more likely that specific banking market failures, perhaps related to relatively high minimum viable scale, are at the heart of African under-performance.

For spatial population characteristics, we include the percentage of the population residing in the largest city, the percent of the population in urban agglomerates, and a measure of population concentration with zero indicating a uniform distribution of residents across $20 \mathrm{~km}$ by $20 \mathrm{~km}$ cells and one indicating that the entire population is concentrated in a single $20 \mathrm{~km}$ by $20 \mathrm{~km}$ cell. For infrastructural development we include roads per square $\mathrm{km}$ and railroad track per square $\mathrm{km}$. For bank penetration, we include commercial bank branches per 100,000 residents (demographic penetration) and branches per sq. km (geographic penetration). Inclusion of many of these variables reduces sample size substantially and their coefficients are insignificant. The results for the variables that do produce significant results (roads per sq.km, percentage of population in the largest city, and the two branch penetration measures) are presented in Table 6.

The population density variable is no longer significant when any of these variables are introduced to the liquid liabilities regressions (in fact it becomes negative and significant when the geographic branch penetration variable is included), suggesting that roads, population in major cities, and bank branch penetration are all relevant factors in understanding the strong link between population density and financial development in Africa. That said, only the coefficients for the 
percentage of population in the largest city and the geographic bank branch penetration measure are consistently significant across the models in Table 6. This pattern is consistent with the notion that physical proximity to providers of financial services accounts for much of the variation in African banking development and thus the minimum viable scale is best achieved in major cities.

It is also worth noting that the links to financial development for the geographic penetration and largest city population variables are significant for liquid liabilities to GDP but not for private credit to GDP. Again, overcoming difficulties associated with population density appears more effective on the savings side than on the credit side.

2. Stock market development: We replace our indicators of banking development with indicators of stock market development, namely stock market capitalization and the value of traded shares, each divided by GDP, and re-run the models in Table 5. These are yearly observations that we average over the sample period for each country as described above. We are unable to run our base models from Table 6 on the sample of African countries because so few of them have indicators of stock market development.

The results (not reported) are notable only because none of the variables that are associated with stock market development in the rest of the developing world are important in Africa. That is, we cannot reject the hypothesis that the relationship between any of the variables in our models and our indicators of African stock market development is zero. This is very likely attributable to the early stage of development of stock markets in Africa. Once these stock markets are better established, it might be easier to analyze the determinants of their development via cross-country regressions. $^{20}$

\footnotetext{
${ }^{20}$ Moreover, Bekaert, Harvey and Lundblad (2005) find that stock market liberalization, leading to free flows of capital in and out of a home country's equity markets, has a causal and positive impact on economic growth. But for most African countries the stock market development (and associated institutions) has not reached the stage of liberalization.
} 


\section{Firm-level Tests on the Access to External Finance}

As mentioned earlier, while cross-country studies focusing on country-level variables are highly useful for summarizing patterns in the data and identifying relationships between variables, they are subject to methodological issues. For example, the observed results may be driven by measurement errors or unobservable factors. In an attempt to overcome these potential problems, we next turn to firm-level data drawn from the Investment Climate Surveys (ICS) conducted by the World Bank over the past decade. ${ }^{21}$ Our specific reasons for augumenting the cross-country study with the firm-level analysis are as follows: First, while country level indicators of banking development might suffer from measurement errors, firm-level responses about their use of financial services should not. Second, our cross-country level regressions involve one observation per country and thus have fewer degrees of freedom than what are available in firm-level regressions. Third, the firm-level data sets allow us to control for a number of potentially relevant firm characteristics (e.g., size, sector) that could explain substantial variation in the demand for, and use of, financial services. Thus, overall the firm-level regressions can provide more precise estimates of the relationships between financial development and our explanatory variables than the country-level regressions. Furthermore, to the extent that we derive similar qualitative results for the firm- and country-level regression, it provides additional, and even stronger, support for the conclusions that we have drawn to this point based only on the country-level regressions.

Table 7 presents summary statistics on our firm-level sample. Firm characteristics (all dummy variables) include size (small, medium, and large based on the number of employees), industry (manufacturing, services, and others), exporter status and foreign ownership status. It appears that there are more small firms and non-exporting firms in the African (excluding South Africa) sample than in other developing countries, while the fraction of firms with foreign

\footnotetext{
${ }^{21}$ These surveys have been used frequently in recent cross-country, firm-level studies on law, institutions, finance and growth (e.g., Beck, Demirgüç-Kunt, and Levine, 2005; Beck, Demirgüç-Kunt, and Maksimovic, 2005).
} 
ownership stakes is higher in the African sample. Firm financing sources, for both short term (working capital) and long term (new investments) purposes, include internal (e.g., retained earnings) and external channels. Following prior research, we focus on long term external financing from financial institutions, the most important external financing channel in most developing countries. Specifically, the external finance dummy equals one if a firm has access to loans from domestic or foreign banks, or credit card debts from these institutions; and zero otherwise. Almost 84\% (74\%) of firms in Africa (other developing countries) do not have access to external finance under this definition. ${ }^{22}$

Our basic strategy is to pattern our firm-level regressions on the country-level regressions, but also to include variables that summarize firm characteristics. We note, however, that we have all of the necessary variables for firms from only twelve countries in Africa. Since the standard errors in our models allow for clustering at the country level, we are not able to include all of the country-level regressors that were in the cross-country regressions in Table 5. However, the most important regressors are included. ${ }^{23}$ Since the majority of firms in Africa and elsewhere do not have access to external finance (Table 7), our dependent variable is a dummy indicating whether the firm received any financing from a formal provider, rather than a continuous variable showing the importance of institutional finance among all financing sources. ${ }^{24}$ Table $^{2}$ reports the marginal effects from Probit regressions.

\footnotetext{
${ }^{22}$ We only include firm observations for which data is available on whether the firm has access to all three external financing channels (domestic and foreign banks and credit cards). Summary statistics reported in Table 7 represent the sample we use in regressions reported in Table 8.

${ }^{23}$ We performed a series of robustness checks in which we added each of the country-level variables from the countrylevel regressions in Table 5 that do not appear in the firm-level regressions in Table 8, one at a time. Qualitative results are very similar to those reported in Table 8.

${ }^{24}$ For the surveys completed through 2006, the dummy variable is equal to one if the firm reported a positive value for finance from local banks, foreign banks or credit cards. For the surveys after 2006, those questions were broadened to ask whether firms received finance from private or state owned commercial banks, or from non-bank financial institutions. Since banks are the main providers of financial services throughout the developing world, this slight change in question format does not present a major problem. Regression results are very similar when we include a post-2006 dummy variable.
} 
In the baseline model, population density is once again positive and significantly associated with firms' access to external finance (Column 1). The coefficient on the interaction between the Africa dummy and population density indicates that there is no difference in the impact of this variable for African and non-African firms. Moreover, we can reject that the sum of the coefficients for density and its interaction with the Africa dummy is zero at the $p=0.05$ level for this model (see chi-squared statistics near the bottom of Table 8). In Model 2 we add road coverage (per sq. km) and find it is actually negatively associated with African firms' access to external finance while it has a positive impact for firms from other developing nations. On the other hand, adding this variable strengthens the (marginally positive) impact of population density for African firms as the interaction with the African dummy is significant at $10 \%$ and the sum of the density and Africa*density coefficients is positive and significantly different from zero at the $5 \%$ level (Column 2).

Another main result from Table 8 is that both the geographic and demographic bank branch penetration variables have a positive association with access to external finance for African countries. However, the result is significant only for geographic penetration (at 1\% in Column 4). These variables are insignificant and of smaller magnitudes in the rest of the developing world. Population density remains positive and significant for non-African countries when the variables for demographic and geographic bank branch penetration enter the regression (Columns 4 and 5). We can no longer reject that the sum of the coefficients for population density and its interaction with the Africa dummy is zero in the model with geographic branch penetration (though we continue to do so when demographic penetration enters the regression in model 5). The results for geographic branch penetration thus confirm those from the country-level regressions. Thus, both cross-country and firm-level regressions point to the importance of physical proximity to providers of financial services in Africa relative to the rest of the developing world. General infrastructural failures are 
not necessarily responsible for low levels of access to external finance for African firms, but rather the failures seem endemic to the banking sectors and markets for debt instruments.

In Table 8 we also introduce foreign bank ownership (at the country level) as an explanatory variable. We did not include this variable in the country-level regressions (Tables 3-5) because we view this as an 'outcome' variable for the development status of a country's banking sector. However, this variable is plausibly exogenous from the point of view of small, privately owned firms in a given region. This variable is negatively associated with access to external finance for firms from the developing world (Column 3), and for Africa (see F-statistic for foreign ownership plus its interaction with the Africa dummy variable at the bottom of column 3). We cannot reject that the sum of the coefficients for population density and its interaction with the Africa dummy is zero in this model, suggesting some interplay between foreign bank presence in Africa and population density. ${ }^{25}$

Finally, we note that firm characteristics explain a substantial amount of variation in firms' access to external finance, supporting the notion that firm-level regressions offer more precise estimates than the country-level regressions. The similarities and differences between Africa and the rest of the developing world are also instructive. Firm size affects the use of external finance similarly in Africa and elsewhere, with smaller firms being at a substantial disadvantage relative to larger ones. Foreign-owned firms use less external finance than local firms in Africa and elsewhere, perhaps because they have access to non-local sources of finance such as their parent companies. Differences also arise with respect to industry affiliation. In the rest of the developing world, manufacturing firms rely more heavily on external finance than other firms. In Africa, those firms show no strong tendency to rely on external finance more than others. In addition, older firms are less likely to have access to external finance outside Africa; but more mature African firms appear

\footnotetext{
${ }^{25}$ The density variable remains negative and significant for the rest of the developing world when foreign bank ownership shares are included in the regression.
} 
to have an advantage in acquiring such finance.

We conclude our cross-country and firm-level analyses with some observations. The crosscountry approach allows us to measure the financial development gap between Africa and other developing economies and identify factors that are of particular relevance for Africa. However, we recognize the limitations with cross-country studies, and hence attempt to address them in three ways. First, we are cautious in drawing causation; we do, however, view variables, such as population density and natural resources endowment, as exogenous variables for predicting financial sector development. Second, as noted above we complement our country-level tests with firm-level analyses, and the micro-level evidence is consistent with the country-level results. In particular, both the cross-country and firm-level studies are consistent with the importance of overcoming low population density to achieve financial development in Africa. Finally, we employ new data on the outreach of financial sectors, in particular bank branch penetration measures, to better understand the channels through which population density may affect different aspects of financial sector development. Moreover, we explore whether transportation infrastructure, urban agglomeration, and the share of arable land are driving the strong relationship between population density and banking sector development in Africa.

\section{Within-country Study: Equity Bank and Financial Access in Kenya}

Our cross-country and firm-level analyses both indicate that sparsely populated regions pose a particularly severe problem for African financial development. What types of financial institutions are best suited to providing services in such areas? A satisfactory answer to this question is well beyond the scope of the current paper, but in this section we examine the effects of the recent expansion of bank branch networks in Kenya to get some sense of the factors that drove a large increase in use of bank accounts and loans within a relatively short time period. 
As background, we begin by noting that while economic growth over the past few decades has been disappointing in Africa, some countries began growing fast at the start of the 21st century, at least until the negative shock of the global crisis in 2007-2009. The GDP growth for the five year period running from 2002 to 2007 averaged over 5\% in Africa, outpacing population growth and hence implying an increase in GDP per capita (Allen, Otchere, and Senbet, 2011). However, and as discussed earlier, despite the adoption of extensive economic and financial reforms, most SubSaharan African countries still face a severe gap in the development of their financial sectors.

Figure 5 shows the relationship between demographic bank penetration (measured by the number of bank branches per 100,000 people) and GDP per capita across low income economies in 2003-2004. The figure suggests three stylized facts. First, there is a strong positive relationship between bank penetration and economic development. Second, Sub-Saharan African countries are characterized by both low income per capita and low bank branch penetration. Third, the bank branch network in Sub-Saharan African countries is underdeveloped relative to not only the higher income economies but other peers with similar income levels.

The underdevelopment of the bank branch network in Sub-Saharan Africa has resulted in low access to banking services, as illustrated by our firm-level study (on the bank credit side). While in the early 2000s roughly half of the world's adult population lacked any form of bank account, in Sub-Saharan Africa over eighty percent of the adult population lacked an account (Chaia et al. (2011) and Honohan (2008)). In line with these facts, Kendall et al. (2010) report that the average number of bank accounts per adult is 3.7 in developed countries, 0.9 in developing countries and less than 0.5 in Sub-Saharan African countries.

The financial access problem in many Sub-Saharan countries and the emergence of new business models that may contribute to solve this problem deserve particular attention. In this respect, Kenya offers an interesting case study for financial access as in recent years it has 
witnessed a strong bank branch expansion. This expansion has coincided with the emergence of Equity Bank, a pioneering commercial bank that devised a banking service strategy targeting low income clients and traditionally under-served territories. The bank is listed on the Nairobi Stock Exchange, it has no government ownership share, and it has played a key role in integrating provision of financial services to the under privileged with formal finance. Figure 6 shows the stock performance of Equity Bank during the period of August, 2006 to August 2011. It significantly outperforms two of its main competitors on this measure, Barclays Bank of Kenya and the Kenya Commercial Bank.

The banking system in Kenya expanded greatly in terms of the number of branches in recent years. Table 9 reports that between 2006 and 2009 the total number of bank branches in Kenya increased from almost 600 to almost 1,000 (a 68\% increase). This bank branch expansion occurred not only in urban districts but also in rural and arid and semi-arid districts. In percentage terms, this expansion was greater in the arid and semi-arid districts (112\%), followed by rural districts (67\%) and urban districts (62\%). This expansion involved all ownership categories of banks, namely domestic private banks, foreign banks and government banks. However, as shown in Table 10, the expansion was particularly driven by domestic private banks, among which Equity Bank played an important role. The number of Equity Bank's branches increased from 44 to 112 in the period 20062009, representing an expansion of $155 \%$. No other bank experienced such growth in the same period. The number of bank branches of Barclays and Kenya Commercial Bank (i.e., the banks with the largest branch networks after Equity Bank) increased from 62 to 119 and from 117 to 169, representing growth of $92 \%$ and $44 \%$ respectively.

Although most Kenyan banks have experienced branch expansion in recent years, banks with different ownership structures have followed different expansion strategies. While foreign banks prefer urban areas (perhaps in order to cherry-pick a set of elite customers), domestic private 
banks seem to exploit their superior knowledge of the culture and have also entered rural and arid and semi-arid areas. For example, as part of its expansion strategy, Equity Bank focused on the use of local languages in its branches. This strategy is quite important considering that $30-40 \%$ of the people in central Kenya cannot speak either English or Swahili, and thus speak only a minority language.

As a first exploration of the bank branching strategies in Kenya, Figure 7 presents the number of bank branches in 2006 and 2009 for three bank groups: foreign banks, governmentowned and government-influenced banks, and domestic private banks. ${ }^{26}$ The figure shows the number of bank branches in districts that have been traditionally less attractive for major commercial banks: rural and arid and semi-arid districts, districts in which minority languages are more common, less populated districts and districts with low educational attainment levels. ${ }^{27}$ It suggests two stylized facts. First, domestic private banks and government and government influenced banks had greater presence in underdeveloped/more vulnerable districts, while foreign banks had the least presence in those districts. Second, the bank branch expansion of local private banks has been much stronger than the branch expansion of government banks and foreign banks. These patterns suggest that domestic private banks, whose expansion has been led by Equity Bank (see Table 10), played a vital role in fostering banking services in underdeveloped districts.

The performance of Equity Bank over the last half decade has been impressive. It has experienced an explosive growth of its assets and a significant expansion of its banking services. Figure 8 shows that during the period 2006-2010 the assets of Equity Bank increased seven-fold; while its customers and customer deposits increased by a factor of six. In fact, Equity Bank ended

\footnotetext{
${ }^{26}$ Government-owned banks are those in which the government owns a majority of shares. In (the two) governmentinfluenced banks the government maintains a large, but non-controlling ownership share. Throughout most of the paper, we refer to both groups collectively as "government banks."

${ }^{27}$ Rural, arid and semi-arid districts exclude Nairobi and Mombasa. High minority language districts are those where the share of the population speaking a minority language is greater than the median. Less populated districts are those where population density is less than the median. Districts with low educational attainment levels are those where the share of the population with secondary or tertiary education is less than the median.
} 
the year 2010 with almost six million customers. Of these, 5.4 million are in Kenya, 474,000 are in Uganda and 28,000 are in South Sudan. As a consequence of this expansion, Equity Bank became the fifth largest bank in Kenya in terms of the share of gross assets and deposits of the whole system and is by far the bank with the largest number of deposit and loan accounts. The number of deposit and loan accounts of Equity Bank represents around the $50 \%$ and $30 \%$ of the total number of deposit and loan accounts in Kenya, respectively (see Table 11). These deposit and loan market shares suggest that the emergence of Equity Bank has played an important role in expanding the bank branch network to under-served territories and thus expanding the use of banking services to population segments ignored by other large traditional commercial banks. Moreover, these stylized facts suggest that Equity Bank’s model has not only expanded the use of financial services to broader segments of the population but it has also created profits in the process. As shown in Figure 8, Equity Bank’s profits before taxes and shareholder funds have experienced a strong positive trend.

There is preliminary evidence that the bank branch expansion and emergence of Equity Bank have paid off in terms of access to banking services in Kenya. In fact, as reported in Table 12, the proportion of individuals having a bank account in Kenya increased considerably going from 14 percent in 2006 to 23 percent in 2009. The proportion of individuals having a loan from a bank showed a more modest increase from 2.9 percent to 4.3 percent. This increase in access to banking services has coincided with a stronger presence of Equity Bank. While Equity Bank had branches in $48 \%$ of the districts in Kenya in 2006, it had branches in $87 \%$ of them in 2009 .

In light of the preliminary evidence presented above, in an ongoing work Allen et al. (2011) explore the impact of Equity Bank, as well as other banks, on the use of banking services in Kenya by combining a new dataset on bank presence with household-level survey data in 2006 and 2009. The dataset on bank presence is based on branch-level information that is aggregated to construct a 
district-level panel on the number of branches by bank (see Allen, et al, for details). The panel covers 45 commercial banks that operated in 65 Kenyan districts in the period between 2006 and 2009. ${ }^{28}$ This new dataset allowed the authors to explore the relationship between bank expansion and access to banking services over time and to exploit within-district variation in bank presence. The household-level data is from the FinAccess surveys conducted by Financial Sector Deepening Trust Kenya (FSD Kenya) in 2006 and 2009. The 2006 survey consisted of 4,420 completed interviews, while the 2009 survey consisted of 6,598 completed interviews.

Allen et al. (2011) find that the presence of domestic private banks, government banks or foreign banks has a positive impact on access to bank accounts at the district level. Interestingly they also find that the presence of Equity Bank in a specific district is strongly positively related to the residents' probability of having a bank account and/or a bank loan, which goes beyond the effect of bank branch expansion and presence of other commercial banks in Kenya. These results are consistent with the stylized facts that we discussed above, and they highlight the importance of institutions, such as Equity Bank, with a business model focused on the provision of financial services to population segments ignored by traditional commercial banks while generating sustainable profits in the process. Such institutions can be an important solution to the financial access problem that has hindered the development of inclusive financial sectors in many developing countries.

\section{Conclusions}

The available evidence provides a convincing linkage between financial development and economic development. Yet the level of financial development remains very low in Africa based

\footnotetext{
${ }^{28}$ Although Kenya is currently divided into 46 districts, the data set exploits a more disaggregated country division as of the 1999 census. In the 1999 census, Kenya comprised eight provinces (Central Coast, Eastern, Nairobi, North Eastern, Nyanza, Rift Valley, and Western) that were subdivided into 69 districts. Of these 69 districts, the survey data consider covers 65.
} 
on the standard indicators of banking and capital market development. Benchmarking based on the correlates of financial development in other developing countries reveals a substantial gap between predicted and actual levels of African financial development. In addition, both country-level and firm-level tests indicate that the determinants of banking development in Africa differ from the rest of the world in telling ways.

For example, inflation and the current account balance explain no variation in African financial development although they do so in other developing countries, and measures of institutional development explain less variation in Africa than elsewhere. Why this collection of macroeconomic fundamentals is not strongly linked to African financial development remains unclear. However, if these macroeconomic and institutional mechanisms could be made to function, our results suggest that the levels of financial development would rise.

Most importantly, population density appears to be more important in Africa than elsewhere, and our firm-level study on the access to external financing indicates that population density is linked more to bank branch penetration in Africa than in the rest of the developing economies. We also find a nonlinear relationship between population density and banking sector development, with the largest gap between Africa and other developing countries observed for those African countries 'trapped' in the low density area. Presumably, bank branch penetration figures remain low in Africa because of difficulties in achieving minimum viable scale in sparsely populated, low-income areas. Therefore, technological advances, such as mobile banking, that enable users of financial services to be located far away from their financial institutions, provide a promising way to facilitate African financial development outside major cities, a topic that has been studied in the context of Kenya, where the mobile payments services of M-PESA are now widely used (Mbiti and Weill, 2010; Jack and Suri, 2010). 
While use of mobile payments services has increased rapidly in Kenya, those services have not proven to be effective vehicles for savings accumulation nor provision of credit (Mbiti and Weill, 2010). We present the stylized facts showing the effects of the expansion of bank branch networks in Kenya from 2006 to 2009 and, in particular, that of Equity Bank. While banks of all ownership types (private, foreign, and government) expanded their networks during this period, Equity's expansion was most pronounced and its association with take-up of bank accounts and loans greater than for other banks. Equity Bank was also more likely to enter previously underserved districts and the association between Equity's presence and increased usage of bank accounts was larger for Kenyans with less wealth and education, that did not own a permanent home, and that lacked a salaried job.

The more detailed analysis of the role of Equity Bank is a subject of an ongoing work by Allen et al (2011), and the current findings support the observations that we make in this paper. Overall, Equity Bank's expansion experience suggests that it is possible to serve poorer segments of the African population while generating sustainable profits. At the same time, we recognize that the last chapter on this topic is yet to be written and that the current configuration of banking services provision in Kenya presents its own challenges. For example, a single bank now maintains $55 \%$ of the deposit accounts in the banking system and, and those deposits are covered by a deposit insurance fund, which could have implications for systemic stability. While we recognize that our contribution is closer to the first than the last word on the determinants of financial development and inclusion in Africa, our hope is that by combining country-, firm-, and household-level analyses, we have been able to shed some light on the contours of the current financial development gap and financial access issue in Africa. 


\section{References}

Alesina, Alberto,, Arnaud. Devleeschauwer, William Easterly, Sergio Kurlat and Romain Wacziarg. 2003. “Fractionalization,” Journal of Economic Growth 8:155-94,

Alfaro, Laura, Sabnem Kalemli-Ozcan, and Vadym Volosovych. 2005. “Why Doesn’t Capital Flow from Rich to Poor Countries? An Empirical Investigation.” NBER Working Paper 11901.

Allen, Franklin, Isaac Otchere, and Lemma Senbet, 2011, “African Financial Systems: A Review,”Review of Development Finance 1, 79-113.

Allen, Franklin, Elena Carletti, Robert Cull, Jun Qian, Lemma Senbet and Patricio Valenzuela, 2011. “Improving Access to Banking: Evidence from Kenya,” working paper, University of Pennsylvania.

Barth, James, Gerard Caprio, and Ross Levine. 2001a. "The Regulation and Supervision of Banks around the World: A New Database.” Policy Research Working Paper 2588. World Bank.

Barth, James R., Gerard Caprio Jr., and Ross Levine. 2001b. "Banking Systems Around the Globe: Do Regulation and Ownership Affect Performance and Stability.” In Frederic S. Mishkin (ed.), Prudential Regulation and Supervision: What Works and What Doesn't. University of Chicago Press, 31--96.

Barth, James R., Gerard Caprio Jr., and Ross Levine. 2004. "Bank Regulation and Supervision; What Works Best?” Journal of Financial Intermediation 13(2):205-248.

Barth, James, Gerard Caprio, Jr., and Ross Levine. 2006. Rethinking Bank Regulation: Till Angels Govern. Cambridge: Cambridge University Press.

Beck, Thorsten, Asli Demirgüç-Kunt, and Ross Levine. 2000. “A New Database on the Structure and Development of the Financial Sector.” World Bank Economic Review 14 (3): 597-605.

Beck, Thorsten, Asli Demirgüç-Kunt and Ross Levine, 2005. "SMEs, Growth and Poverty: Crosscountry Evidence,” Journal of Economic Growth 10, 199-229.

Beck, Thorsten, Asli Demirgüç-Kunt, and Ross Levine. 2007. "Finance, Inequality, and the Poor." Journal of Economic Growth 12(1): 27-49.

Beck, Thorsten, Asli Demirgüç-Kunt, and Vojislav Maksimovic, 2005. "Financial and Legal Constraints to Firm Growth: Does Size Matter?” Journal of Finance 60, 137-177.

Beck, Thorsten, Asli Demirguc-Kunt, and Maria Soledad Martinez Peria, Maria Soledad, 2007, Reaching out: Access to and use of banking services across countries, Journal of Financial Economics 85, 234-266. 
Beck, Thorsten, Erik Feyen, Alain Ize, and Florencia Moizeszowicz, 2008. "Benchmarking Financial Development.” Policy Research Working Paper 4638. World Bank, Washington DC.

Bekaert, Geert, Campbell Harvey, and Christian Lundblad, 2005. "Does Financial Liberalization Spur Growth?” Journal of Financial Economics 77, 3-55.

Chaia, Alberto, Aparna Dalal, Tony Goland, Maria Jose Gonzalez, Jonathan Morduch, and Robert Schiff, 2011, Half the World is Unbanked, New York University, working paper.

Claessens, Stijn, Asli Demirguc-Kunt, and Harry Huizinga, 2001. "How Does Foreign Entry Affect Domestic Banking Markets?” Journal of Banking and Finance 25 (5), 891-911.

Claessens, Stijn and Luc Laeven, 2003. "What Drives Bank Competition? Some International Evidence.” Journal of Money, Credit and Banking 36(3), 563-83.

Claessens, Stijn and Lee, J. K., 2003. "Foreign Banks in Low-Income Countries: Recent Developments and Impacts." in Hanson, J., Honohan, P. and Majnoni, G. (eds.). Globalization and National Financial Systems. The World Bank, Washington D.C.

Clarke, George R.G., L. Colin Xu, and Heng-Fu Zou, 2006. "Fianance and Income Inequality: What Do the Data Tell Us?” Southern Economic Journal 72(3): 578-596.

Cull, Robert and Laurie Effron, 2008. "World Bank Lending and Financial Sector Development.” World Bank Economic Review 22(2): 315-343.

Cull, Robert and Maria Soledad Martinez Peria, 2008. "Crises as Catalysts for Foreign Bank Activity in Emerging Markets.” In Justin Robertson, (ed.), Power and Politics after Financial Crises. New York: Palgrave Macmillan.

Cull Robert, Lemma W. Senbet and Marco Sorge, 2005. "Deposit Insurance and Financial Development.” Journal of Money, Credit, and Banking, 37(1): 43-82.

Detragiache, Enrica, Thierry Tressel, and Poonam Gupta, 2006. "Foreign Banks in Poor Countries: Theory and Evidence.” IMF Working Paper WP/06/18.

Easterly, William and Ross Levine, 1997. "Africa’s Growth Tragedy: Policies and Ethnic Divisions,” Quarterly Journal of Economics, 112(4): 1203-1250.

Equity Bank, 2010, Equity Bank’s Annual Report and Financial Statements 2010. Downloaded from http://www.equitybank.co.ke/investors.php?subcat=6.

Fan, Joseph P.H., Randall Morck, Lixin Colin Xu, and Bernard Yeung, forthcoming. "Does 'Good Government’ Draw Foreign Capital? Explaining China’s Exceptional Foreign Direct Investment Flow.” World Development. 
Honohan, Patrick, 2008, Cross-Country Variation in Household Access to Financial Services, Journal of Banking and Finance 32, 2493-2500.

Honohan, Patrick and Thorsten Beck, eds., 2007, Making Finance Work for Africa, World Bank publication volume.

Jack, William, and Tavneet Suri, 2010. “The Economics of M-PESA.” MIT Sloan, working paper.

Kamil, Herman, and Kulwant Rai, 2010. “The Global Credit Crunch and Foreign Banks' Lending to Emerging Markets: Why did Latin America Fare Better?” IMF working paper 10/102.

Kendall, Jake, Nataliya Mylenko and Alejandro Ponce, 2010, Measuring Financial Access around the World, World Bank Policy Research Working Paper 5253.

Kaufmann, Daniel, Aart Kraay, and Massimo Mastruzzi, 2007. “Governance Matters VI: Governance Indicators of 1996-2006.” World Bank Policy Research Working Paper 4280, Washington, DC.

La Porta Rafael, Florencio Lopez-de-Silanes, Andrei Shleifer, and Robert W. Vishny, 1997. “Legal Determinants of External Finance,” Journal of Finance, 52(3): 1131-1150.

La Porta, Rafael, Florencio Lopez-de-Silanes, and Andrei Shleifer, 2002. “Government Ownership of Banks,” Journal of Finance, 57(1): 265-301.

Lederman, Daniel, and William F. Maloney. 2008. "In Search of the Missing Resource Curse." Economía 9(1): 1-58.

Levine, Ross. 2005. “Finance and Growth: Theory and Evidence.” In Philippe Aghion and Steven Durlauf (eds.), Handbook of Economic Growth. Amsterdam: Elsevier Science.

Levine, Ross, Norman Loayza, and Thorsten Beck. 2000. "Financial Intermediation and Growth: Causality and Causes.” Journal of Monetary Economics 46 (1): 31-77.

Levine, Ross and David Renelt. 1992. “A Sensitivity Analysis of Cross-Country Growth Regressions.” American Economic Review 82(4):942-63.

Loayza N. and R. Ranciere. 2006. “Financial Development, Financial Fragility, and Growth,” Journal of Money, Credit, and Banking, 38, 1051-1076.

Martinez Peria, M. and A. Mody, 2004. "How Foreign Participation and Market Concentration Impact Bank Spreads.” Journal of Money, Credit, and Banking 36 (3), 511-537.

Mbiti, Isaac, and David Weil, 2010. “Mobile Banking: The Impact of M-Pesa in Kenya,” NBER working paper.

Mian, Atif. "Foreign, Private Domestic, and Government Banks: New Evidence from Emerging Markets.” Journal of Banking and Finance, forthcoming. 
Nissanke, Machiko and and Ernest Aryeetey 1998. Financial Integration and Development in SubSaharan Africa, ODI and Routledge, London and New York.

Pritchett, Lant. 1997. “Divergence, Big Time.” Journal of Economic Perspectives 11(3): 3-17.

Rajan, Raghuram G., and Luigi Zingales.1998. "Financial Dependence and Growth.” American Economic Review 88 (3): 559-86.

Sachs, Jeffrey D. and Andrew Warner. 1995. "Natural Resource Abundance and Economic Growth.” National Bureau of Economic Research Working Paper 5398, Cambridge, MA.

Sachs, Jeffrey D. and Andrew Warner. 2001. “The Curse of Natural Resources.” European Economic Review 45: 827-838.

Senbet, Lemma and Isaac Otchere, 2008. "Financial Sector Reforms in Africa: Perspectives on Issues and Policies”, World Bank Volume - Annual Bank Conference on Development Economics, eds. Francois Bourgignon and Boris Pleskovic: 81-119. 
Table 1: Summary Statistics on the Country Sample

\begin{tabular}{|l|c|c|c|c|}
\hline \multirow{2}{*}{\multicolumn{1}{|c|}{ Variable }} & \multicolumn{2}{c|}{ World (minus Africa) } & \multicolumn{2}{c|}{ Sub-Saharan Africa } \\
\cline { 2 - 5 } & Mean & Standard & Mean & $\begin{array}{c}\text { Standard } \\
\text { Deviation }\end{array}$ \\
\hline Liquid liabilities / GDP & & $47.4 \%$ & $27.5 \%$ & $17.7 \%$ \\
Private credit / GDP & $64.2 \%$ & $45.3 \%$ & $17.6 \%$ & $22.7 \%$ \\
Stock Market Capitalization / GDP & $57.7 \%$ & $60.0 \%$ & $25.6 \%$ & $43.8 \%$ \\
Stock Market Value Traded / GDP & $52.1 \%$ & $50.9 \%$ & $6.5 \%$ & $20.0 \%$ \\
Ln(Population) & $34.1 \%$ & 1.59 & 2.24 & 1.33 \\
Ln(Population density) & 2.44 & 1.94 & 0.09 & 0.12 \\
Natural resources & 0.44 & 2.41 & 0.15 & 0.77 \\
Offshore center & 0.5 & $20.7 \%$ & $0.0 \%$ & $0.0 \%$ \\
Ln(Per capita income) & $4.4 \%$ & 1.04 & 0.38 & 0.94 \\
Population * GDP per capita & 2.25 & 1.35 & 0.03 & 0.07 \\
Real GDP growth rate & 0.48 & $2.5 \%$ & $4.8 \%$ & $2.7 \%$ \\
Inflation rate & $4.1 \%$ & $5.2 \%$ & $9.3 \%$ & $15.0 \%$ \\
Current Account balance / GDP & $5.2 \%$ & $8.1 \%$ & $-3.8 \%$ & $6.7 \%$ \\
KKM index & $0.2 \%$ & 0.9 & -0.54 & 0.58 \\
Bank concentration & 0.33 & 0.19 & 0.81 & 0.14 \\
Foreign ownership share & 0.65 & $25.9 \%$ & $44.4 \%$ & $24.4 \%$ \\
State ownership share & $27.1 \%$ & $19.7 \%$ & $13.3 \%$ & $16.6 \%$ \\
Manufacturing / GDP & $15.9 \%$ & $6.1 \%$ & $11.0 \%$ & $7.3 \%$ \\
Secondary/Primary school enrollment & $16.8 \%$ & 0.24 & 0.33 & 0.18 \\
Roads / Area & 0.81 & 1.65 & 0.21 & 0.22 \\
Railroads / Area & 1.07 & 0.03 & 0 & 0 \\
Urban population & 0.03 & $20.7 \%$ & $36.2 \%$ & $17.2 \%$ \\
Geographic branch penetration & $63.6 \%$ & 80.07 & 7.97 & 22.49 \\
Demographic branch penetration & 29.76 & 17.28 & 2.86 & 3.64 \\
\hline
\end{tabular}

Data sources: For liquid liabilities/GDP, private credit/GDP, stock market capitalization/GDP, stock market value traded/GDP, and bank concentration: World Bank Database on Financial Development and Structure. See Thorsten Beck and Asli Demirgüç-Kunt, "Financial Institutions and Markets Across Countries and over Time: Data and Analysis"', World Bank Policy Research Working Paper No. 4943, May 2009. Natural resources is the Lederman and Maloney (2008) measure of net exports in resource intensive industries as described in the text. Offshore center is a dummy variable defined by IMF (2007), "Financial Soundness Indicators: Experience with the Coordinated Compilation Exercise and Next Steps", STA Dept. The KKM index is the measure of broad institutional development created by Kaufmann, Kraay, and Maztruzzi (2007). Foreign and state ownership share of banking sector assets are from the World Bank Database of Bank Regulation and Supervision (2008). Geographic and demographic branch penetration are from CGAP, "Financial Access 2009: Measuring Access to Financial Services in 135 Countries.” All other variables are from World Development Indicators. 
Table 2: Correlations Tests: World (minus Africa) sample

\begin{tabular}{|c|c|c|c|c|c|c|c|c|c|c|c|c|c|c|c|c|c|c|}
\hline $\mathrm{N}=90$ & $\begin{array}{l}\text { Liquid } \\
\text { liab./ } \\
\text { GDP }\end{array}$ & $\begin{array}{c}\text { Priv } \\
\text { credit } \\
\text { / GDP }\end{array}$ & $\begin{array}{c}\text { Stock } \\
\text { mkt } \\
\text { capit } \\
\text { / GDP }\end{array}$ & $\begin{array}{c}\text { Stock } \\
\text { mkt val } \\
\text { traded / } \\
\text { GDP }\end{array}$ & Ln(Pop) & $\begin{array}{l}\text { Ln(Pop } \\
\text { density) }\end{array}$ & $\begin{array}{l}\text { Nat } \\
\text { res }\end{array}$ & $\begin{array}{l}\text { Offsh } \\
\text { center }\end{array}$ & $\begin{array}{c}\text { Ln(Per } \\
\text { capita } \\
\text { income })\end{array}$ & $\begin{array}{c}\text { Pop * } \\
\text { GDP } \\
\text { per } \\
\text { capita }\end{array}$ & $\begin{array}{c}\text { Real } \\
\text { GDP } \\
\text { gr. rate }\end{array}$ & $\begin{array}{l}\text { Infl. } \\
\text { rate }\end{array}$ & $\begin{array}{c}\text { CA } \\
\text { balance } \\
\text { / GDP }\end{array}$ & $\begin{array}{l}\text { KKM } \\
\text { index }\end{array}$ & $\begin{array}{l}\text { Bank } \\
\text { conc }\end{array}$ & $\begin{array}{c}\text { Forgn } \\
\text { own } \\
\text { share }\end{array}$ & $\begin{array}{l}\text { State } \\
\text { own } \\
\text { share }\end{array}$ & $\begin{array}{l}\text { Manuf } \\
\text { / GDP }\end{array}$ \\
\hline Private credit / GDP & $0.64 *$ & 1 & & & & & & & & & & & & & & & & \\
\hline $\begin{array}{l}\text { Stock market } \\
\text { capitalization / GDP }\end{array}$ & $0.68^{*}$ & $0.65 *$ & 1 & & & & & & & & & & & & & & & \\
\hline $\begin{array}{l}\text { Stock market value traded } \\
\text { / GDP }\end{array}$ & $0.40 *$ & $0.70^{*}$ & $0.75^{*}$ & 1 & & & & & & & & & & & & & & \\
\hline Ln(Population) & -0.08 & 0.03 & -0.02 & $0.24 *$ & 1 & & & & & & & & & & & & & \\
\hline Ln(Population density) & $0.38 *$ & 0.13 & $0.61 *$ & 0.10 & -0.20 & 1 & & & & & & & & & & & & \\
\hline Natural resources & $-0.22 *$ & 0.06 & -0.06 & 0.03 & -0.19 & $-0.21 *$ & 1 & & & & & & & & & & & \\
\hline Offshore center & 0.19 & 0.10 & 0.08 & -0.08 & $-0.25 *$ & $0.41^{*}$ & -0.07 & 1 & & & & & & & & & & \\
\hline Ln(Per capita income) & $0.49 *$ & $0.71^{*}$ & $0.51 *$ & $0.51^{*}$ & -0.15 & 0.18 & $0.22 *$ & 0.04 & 1 & & & & & & & & & \\
\hline $\begin{array}{l}\text { Population * GDP per } \\
\text { capita }\end{array}$ & 0.13 & $0.38 *$ & 0.18 & $0.47^{*}$ & $0.47^{*}$ & -0.05 & -0.12 & -0.07 & $0.26^{*}$ & 1 & & & & & & & & \\
\hline Real GDP growth rate & -0.17 & $-0.36^{*}$ & -0.20 & $-0.25^{*}$ & -0.18 & $0.31^{*}$ & 0.00 & $0.22 *$ & $-0.26^{*}$ & -0.19 & 1 & & & & & & & \\
\hline Inflation rate & $-0.40^{*}$ & $-0.48 *$ & $-0.35^{*}$ & $-0.32 *$ & 0.15 & -0.18 & -0.08 & -0.16 & $-0.39 *$ & -0.10 & -0.04 & 1 & & & & & & \\
\hline $\begin{array}{l}\text { Current Account balance } \\
\text { / GDP }\end{array}$ & $0.37 *$ & $0.22 *$ & $0.45^{*}$ & $0.27 *$ & 0.02 & $0.58^{*}$ & $0.25 *$ & 0.18 & $0.34^{*}$ & -0.02 & 0.09 & -0.17 & 1 & & & & & \\
\hline KKM index & $0.51 *$ & $0.79 *$ & $0.51 *$ & $0.50^{*}$ & -0.19 & 0.13 & 0.16 & 0.01 & $0.88^{*}$ & $0.21 *$ & $-0.27^{*}$ & $-0.48 *$ & 0.17 & 1 & & & & \\
\hline Bank concentration & -0.11 & 0.01 & 0.12 & 0.04 & $-0.50 *$ & 0.07 & 0.21 & -0.02 & 0.03 & $-0.35 *$ & -0.03 & -0.16 & -0.06 & 0.18 & 1 & & & \\
\hline Foreign ownership share & 0.08 & -0.17 & -0.02 & $-0.25^{*}$ & $-0.43^{*}$ & 0.21 & -0.09 & 0.15 & 0.14 & $-0.23 *$ & 0.11 & -0.13 & 0.02 & 0.14 & 0.08 & 1 & & \\
\hline State ownership share & -0.14 & $-0.28 *$ & $-0.28 *$ & -0.14 & $0.43^{*}$ & -0.11 & -0.09 & -0.15 & $-0.41^{*}$ & -0.03 & 0.08 & $0.26^{*}$ & -0.05 & $-0.39 *$ & -0.16 & $-0.32 *$ & 1 & \\
\hline Manufacturing / GDP & -0.07 & 0.08 & -0.15 & -0.02 & $0.35 *$ & -0.18 & $-0.26 *$ & -0.12 & 0.03 & 0.05 & -0.07 & 0.06 & -0.15 & 0.10 & $-0.22 *$ & -0.02 & 0.11 & 1 \\
\hline $\begin{array}{l}\text { Secondary/Primary } \\
\text { school enrollment }\end{array}$ & $0.25 *$ & $0.51^{*}$ & $0.27^{*}$ & $0.34 *$ & -0.18 & -0.01 & $0.25^{*}$ & -0.12 & $0.76^{*}$ & 0.14 & -0.15 & $-0.32 *$ & 0.08 & $0.76^{*}$ & 0.19 & 0.16 & $-0.33^{*}$ & 0.07 \\
\hline
\end{tabular}

Notes: $(* \mathrm{p}<0.05)$ 


\section{Table 3: Regressions on Banking Sector Development for the sample of non-African countries}

This table presents OLS regressions of banking sector development, measured by liquid liabilities/GDP and credit to the private sector extended by deposit money banks/GDP ratios, on a set of country-level variables including endowment (population and resources), macroeconomics, institutions, banking structure and other variables. We present models for all non-African countries and for (non-African) low and middle income countries separately. Standard errors are presented in the brackets below coefficients.

\begin{tabular}{|c|c|c|c|c|c|c|c|c|}
\hline & \multicolumn{4}{|c|}{ Liquid liabilities / GDP } & \multicolumn{4}{|c|}{ Private credit / GDP } \\
\hline & \multicolumn{2}{|c|}{ All } & \multicolumn{2}{|c|}{ Low + Middle income } & \multicolumn{2}{|c|}{ All } & \multicolumn{2}{|c|}{ Low + Middle income } \\
\hline & (1) & (2) & (3) & (4) & (5) & (6) & (7) & (8) \\
\hline \multirow[t]{2}{*}{ Ln(Population) } & -0.017 & -0.003 & -0.001 & -0.035 & 0.003 & 0.015 & 0.002 & -0.027 \\
\hline & $(0.021)$ & $(0.028)$ & $(0.019)$ & $(0.030)$ & $(0.018)$ & $(0.021)$ & $(0.017)$ & $(0.026)$ \\
\hline \multirow[t]{2}{*}{ Ln(Population Density) } & $0.074 * * *$ & 0.031 & 0.036 & 0.032 & 0.018 & 0.019 & $0.032 *$ & -0.020 \\
\hline & $(0.023)$ & $(0.027)$ & $(0.022)$ & $(0.022)$ & $(0.019)$ & $(0.020)$ & $(0.019)$ & $(0.019)$ \\
\hline \multirow[t]{2}{*}{ Natural Resources } & $-0.038 * * *$ & $-0.069 * * *$ & -0.034 & $-0.062^{*}$ & $-0.022^{*}$ & 0.0002 & -0.010 & -0.026 \\
\hline & $(0.014)$ & $(0.019)$ & $(0.033)$ & $(0.036)$ & $(0.012)$ & $(0.014)$ & $(0.028)$ & $(0.031)$ \\
\hline \multirow[t]{2}{*}{ Offshore Center } & $0.247^{*}$ & 0.133 & $0.369 * * *$ & $0.341 * * *$ & 0.191 & 0.159 & $0.374 * * *$ & $0.339 * * *$ \\
\hline & $(0.145)$ & $(0.170)$ & $(0.112)$ & $(0.121)$ & $(0.123)$ & $(0.127)$ & $(0.096)$ & $(0.102)$ \\
\hline \multirow{2}{*}{ Ln(Per Capita Income) } & $0.222 * * *$ & 0.061 & 0.056 & -0.091 & $0.275^{* * *}$ & -0.016 & $0.089 * *$ & -0.063 \\
\hline & $(0.036)$ & $(0.083)$ & (0.039) & $(0.065)$ & $(0.031)$ & $(0.062)$ & $(0.034)$ & $(0.055)$ \\
\hline \multirow[t]{2}{*}{ Population * GDP Per Capita } & 0.004 & -0.013 & 0.006 & 0.061 & $0.071^{* *}$ & $0.062^{* *}$ & -0.031 & 0.015 \\
\hline & $(0.032)$ & $(0.033)$ & $(0.100)$ & $(0.101)$ & $(0.027)$ & $(0.024)$ & $(0.086)$ & $(0.084)$ \\
\hline \multirow[t]{2}{*}{ Real GDP Growth Rate } & & -2.015 & & $-2.619 * *$ & & $-3.129 * * *$ & & $-1.769 * *$ \\
\hline & & $(1.514)$ & & $(1.159)$ & & $(1.126)$ & & $(0.974)$ \\
\hline \multirow[t]{2}{*}{ Inflation Rate } & & -1.219 & & $-0.946^{*}$ & & $-1.092 * *$ & & $-0.894 * *$ \\
\hline & & $(0.751)$ & & $(0.505)$ & & $(0.559)$ & & $(0.424)$ \\
\hline \multirow[t]{2}{*}{ Current Account Balance / GDP } & & $1.519^{* * *}$ & & $1.565^{* *}$ & & 0.392 & & $1.236 * *$ \\
\hline & & $(0.556)$ & & $(0.658)$ & & $(0.414)$ & & $(0.553)$ \\
\hline \multirow[t]{2}{*}{ KKM Index } & & $0.239 * * *$ & & $0.215^{* * *}$ & & $0.362 * * *$ & & $0.210^{* * *}$ \\
\hline & & $(0.093)$ & & $(0.080)$ & & $(0.069)$ & & $(0.067)$ \\
\hline \multirow[t]{2}{*}{ Manufacturing / GDP } & & $-1.313^{* *}$ & & 0.436 & & -0.127 & & 0.651 \\
\hline & & $(0.652)$ & & $(0.580)$ & & $(0.485)$ & & $(0.487)$ \\
\hline \multirow[t]{2}{*}{ Secondary/Primary Enrollment } & & -0.335 & & -0.040 & & -0.130 & & -0.004 \\
\hline & & $(0.241)$ & & $(0.179)$ & & $(0.179)$ & & $(0.150)$ \\
\hline \multirow[t]{2}{*}{ Constant } & $0.383^{* * *}$ & $1.188 * * *$ & $0.467 * * *$ & $0.990 * * *$ & -0.041 & $0.782^{* * *}$ & $0.248^{* * *}$ & $0.640^{* * *}$ \\
\hline & $(0.123)$ & $(0.223)$ & $(0.101)$ & $(0.167)$ & $(0.104)$ & $(0.166)$ & $(0.087)$ & $(0.141)$ \\
\hline Adjusted R2 & 0.41 & 0.51 & 0.14 & 0.36 & 0.54 & 0.70 & 0.22 & 0.43 \\
\hline Observations/Countries & 111 & 97 & 75 & 67 & 111 & 97 & 75 & 67 \\
\hline
\end{tabular}

Notes: $\left({ }^{*} \mathbf{p}<0.1,{ }^{* *} \mathbf{p}<0.05,{ }^{* * *} \mathbf{p}<0.01\right)$. 


\section{Table 4: Regressions on Banking Development for the sample of African countries}

This table presents OLS regressions of banking sector development, measured by liquid liabilities/GDP and credit to the private sector from deposit money banks/GDP ratios, on a set of country-level variables including endowment (population and resources), macroeconomics, institutions, banking structure and other variables. We present models for all the sub-Saharan African countries, with and without South Africa. Standard errors are presented in the brackets below coefficients.

\begin{tabular}{|c|c|c|c|c|c|c|c|c|}
\hline & \multicolumn{4}{|c|}{ Liquid liabilities / GDP } & \multicolumn{4}{|c|}{ Private credit / GDP } \\
\hline & \multicolumn{2}{|c|}{ All } & \multicolumn{2}{|c|}{ Without South Africa } & \multicolumn{2}{|c|}{ All } & \multicolumn{2}{|c|}{ Without South Africa } \\
\hline & $(1)$ & (2) & (3) & (4) & (5) & (6) & (7) & (8) \\
\hline Ln(Population) & $\begin{array}{l}-0.035 \\
(0.026)\end{array}$ & $\begin{array}{l}-0.004 \\
(0.026)\end{array}$ & $\begin{array}{l}-0.029 \\
(0.031)\end{array}$ & $\begin{array}{c}-0.011 \\
(0.030)\end{array}$ & $\begin{array}{c}-0.058 * * \\
(0.024)\end{array}$ & $\begin{array}{l}-0.021 \\
(0.023)\end{array}$ & $\begin{array}{l}-0.007 \\
(0.022)\end{array}$ & $\begin{array}{c}0.013 \\
(0.021)\end{array}$ \\
\hline Ln(Population Density) & $\begin{array}{c}0.074 * * * \\
(0.019)\end{array}$ & $\begin{array}{c}0.080 * * * \\
(0.022)\end{array}$ & $\begin{array}{c}0.075^{* * *} \\
(0.020)\end{array}$ & $\begin{array}{c}0.077 * * * \\
(0.024)\end{array}$ & $\begin{array}{c}0.0314 * \\
(0.018)\end{array}$ & $\begin{array}{c}0.049 * * \\
(0.020)\end{array}$ & $\begin{array}{c}0.043 * * * \\
(0.014)\end{array}$ & $\begin{array}{c}0.061^{* * * *} \\
(0.016)\end{array}$ \\
\hline Natural Resources & $\begin{array}{l}-0.033 \\
(0.036)\end{array}$ & $\begin{array}{l}-0.013 \\
(0.047)\end{array}$ & $\begin{array}{l}-0.032 \\
(0.037)\end{array}$ & $\begin{array}{l}-0.010 \\
(0.049)\end{array}$ & $\begin{array}{l}-0.030 \\
(0.033)\end{array}$ & $\begin{array}{l}-0.001 \\
(0.041)\end{array}$ & $\begin{array}{c}-0.024 \\
(0.027)\end{array}$ & $\begin{array}{l}-0.015 \\
(0.034)\end{array}$ \\
\hline Offshore Center & - & - & - & - & - & - & - & - \\
\hline Ln(Per Capita Income) & $\begin{array}{c}0.038 \\
(0.035)\end{array}$ & $\begin{array}{c}0.022 \\
(0.078)\end{array}$ & $\begin{array}{c}0.043 \\
(0.037)\end{array}$ & $\begin{array}{c}0.018 \\
(0.080)\end{array}$ & $\begin{array}{c}0.009 \\
(0.032)\end{array}$ & $\begin{array}{c}0.054 \\
(0.068)\end{array}$ & $\begin{array}{c}0.048^{*} \\
(0.027)\end{array}$ & $\begin{array}{c}0.073 \\
(0.056)\end{array}$ \\
\hline Population * GDP Per Capita & $\begin{array}{c}0.441 \\
(0.520)\end{array}$ & $\begin{array}{c}-0.281 \\
(0.508)\end{array}$ & $\begin{array}{l}0.057 \\
(1.12)\end{array}$ & $\begin{array}{c}0.221 \\
(1.197)\end{array}$ & $\begin{array}{c}2.941^{* * *} \\
(0.477)\end{array}$ & $\begin{array}{c}2.396 * * * \\
(0.442)\end{array}$ & $\begin{array}{l}-0.141 \\
(0.816)\end{array}$ & $\begin{array}{l}-0.163 \\
(0.834)\end{array}$ \\
\hline Real GDP Growth Rate & & $\begin{array}{c}-0.447 \\
(1.031)\end{array}$ & & $\begin{array}{l}-0.499 \\
(1.057)\end{array}$ & & $\begin{array}{l}-0.607 \\
(0.898)\end{array}$ & & $\begin{array}{l}-0.343 \\
(0.736)\end{array}$ \\
\hline Inflation Rate & & $\begin{array}{c}0.060 \\
(0.192)\end{array}$ & & $\begin{array}{c}0.058 \\
(0.196)\end{array}$ & & $\begin{array}{c}-0.076 \\
(0.167)\end{array}$ & & $\begin{array}{l}-0.066 \\
(0.136)\end{array}$ \\
\hline Current Account Balance / GDP & & $\begin{array}{c}-0.082 \\
(0.587)\end{array}$ & & $\begin{array}{l}-0.207 \\
(0.656)\end{array}$ & & $\begin{array}{l}-0.879^{*} \\
(0.511)\end{array}$ & & $\begin{array}{l}-0.241 \\
(0.457)\end{array}$ \\
\hline KKM Index & & $\begin{array}{l}0.116^{*} \\
(0.062)\end{array}$ & & $\begin{array}{l}0.119^{*} \\
(0.063)\end{array}$ & & $\begin{array}{c}0.073 \\
(0.054)\end{array}$ & & $\begin{array}{c}0.058 \\
(0.044)\end{array}$ \\
\hline Manufacturing / GDP & & $\begin{array}{l}-0.376 \\
(0.455)\end{array}$ & & $\begin{array}{l}-0.341 \\
(0.470)\end{array}$ & & $\begin{array}{l}-0.085 \\
(0.396)\end{array}$ & & $\begin{array}{l}-0.265 \\
(0.327)\end{array}$ \\
\hline Secondary/Primary Enrollment & & $\begin{array}{c}0.372 \\
(0.247)\end{array}$ & & $\begin{array}{c}0.379 \\
(0.252)\end{array}$ & & $\begin{array}{c}0.179 \\
(0.215)\end{array}$ & & $\begin{array}{c}0.144 \\
(0.175)\end{array}$ \\
\hline Constant & $\begin{array}{c}0.548 * * * \\
(0.078)\end{array}$ & $\begin{array}{c}0.528 * * * \\
(0.2613)\end{array}$ & $\begin{array}{c}0.545^{* * *} \\
(0.079)\end{array}$ & $\begin{array}{c}0.518 * * * \\
(0.3044)\end{array}$ & $\begin{array}{c}0.297 * * * \\
(0.071)\end{array}$ & $\begin{array}{l}0.260 * \\
(0.130)\end{array}$ & $\begin{array}{c}0.275^{* * *} \\
(0.058)\end{array}$ & $\begin{array}{c}0.309 * * * \\
(0.243)\end{array}$ \\
\hline Adjusted R2 & 0.36 & 0.53 & 0.34 & 0.52 & 0.64 & 0.78 & 0.24 & 0.45 \\
\hline Observations/Countries & 38 & 33 & 37 & 32 & 38 & 33 & 37 & 32 \\
\hline
\end{tabular}

Notes: $\left({ }^{*} \mathbf{p}<0.1,{ }^{* *} \mathbf{p}<0.05,{ }^{* * *} \mathbf{p}<0.01\right)$. 
Table 5: Regressions for the combined sample of low and middle income and African countries

This table presents OLS regressions of banking sector development, measured by liquid liabilities/GDP and credit to the private sector from deposit money banks/GDP ratios, on a set of country-level variables including endowment (population and resources), macroeconomics, institutions, banking structure and other variables. We include all the low and middle income countries (including Africa, excluding South Africa), an African dummy variable, and interactions between each of our explanatory variables and the Africa dummy. Standard errors are presented in the brackets below coefficients, and Fstatistics are shown at the bottom of the table.

\begin{tabular}{|c|c|c|c|c|c|c|}
\hline & \multicolumn{3}{|c|}{ Liquid Liabilities/GDP } & \multicolumn{3}{|c|}{ Private Credit/GDP } \\
\hline & (1) & (2) & (3) & (4) & (5) & (6) \\
\hline \multirow[t]{2}{*}{ Africa } & $-0.105^{*}$ & 0.078 & $-0.472 *$ & -0.066 & 0.027 & -0.331 \\
\hline & $(0.054)$ & $(0.147)$ & $(0.280)$ & $(0.045)$ & $(0.124)$ & $(0.231)$ \\
\hline \multirow[t]{2}{*}{ Ln(Population) } & -0.009 & -0.001 & -0.035 & 0.0005 & 0.002 & -0.027 \\
\hline & $(0.015)$ & $(0.017)$ & $(0.028)$ & $(0.013)$ & $(0.015)$ & $(0.023)$ \\
\hline \multirow[t]{2}{*}{ Ln(Population Density) } & $0.050 * * *$ & $0.036^{*}$ & 0.032 & $0.036 * * *$ & $0.032 *$ & 0.020 \\
\hline & $(0.016)$ & $(0.019)$ & $(0.020)$ & $(0.013)$ & $(0.016)$ & $(0.017)$ \\
\hline \multirow[t]{2}{*}{ Natural Resources } & -0.031 & -0.034 & $-0.062 *$ & -0.012 & -0.010 & -0.026 \\
\hline & $(0.025)$ & $(0.030)$ & $(0.033)$ & $(0.021)$ & $(0.025)$ & $(0.027)$ \\
\hline \multirow[t]{2}{*}{ Offshore Center } & $0.363^{* * *}$ & $0.369 * * *$ & $0.341 * * *$ & $0.378 * * *$ & $0.374 * * *$ & $0.339 * * *$ \\
\hline & $(0.098)$ & $(0.101)$ & $(0.110)$ & $(0.082)$ & $(0.085)$ & $(0.091)$ \\
\hline \multirow[t]{2}{*}{ Ln(Per Capita Income) } & $0.052^{* *}$ & 0.056 & -0.091 & $0.070 * * *$ & $0.089 * * *$ & -0.063 \\
\hline & $(0.026)$ & $(0.035)$ & $(0.059)$ & $(0.022)$ & $(0.030)$ & $(0.049)$ \\
\hline \multirow[t]{2}{*}{ Population * GDP Per Capita } & 0.030 & 0.006 & 0.061 & -0.023 & -0.031 & 0.015 \\
\hline & $(0.084)$ & $(0.089)$ & $(0.091)$ & $(0.071)$ & $(0.075)$ & $(0.075)$ \\
\hline \multirow[t]{2}{*}{ Real GDP Growth Rate } & & & $-2.619 * *$ & & & $-1.769 * *$ \\
\hline & & & $(1.053)$ & & & $(0.869)$ \\
\hline \multirow[t]{2}{*}{ Inflation Rate } & & & $-0.946^{* *}$ & & & $-0.894 * *$ \\
\hline & & & $(0.458)$ & & & $(0.378)$ \\
\hline \multirow[t]{2}{*}{ Current Account Balance / GDP } & & & $1.565^{* *}$ & & & $1.236 * *$ \\
\hline & & & $(0.598)$ & & & $(0.493)$ \\
\hline \multirow[t]{2}{*}{ KKM Index } & & & $0.215^{* * *}$ & & & $0.210 * * *$ \\
\hline & & & $(0.072)$ & & & $(0.060)$ \\
\hline \multirow[t]{2}{*}{ Manufacturing / GDP } & & & 0.436 & & & 0.651 \\
\hline & & & $(0.526)$ & & & $(0.434)$ \\
\hline \multirow[t]{2}{*}{ Secondary/Primary Enrollment } & & & -0.040 & & & -0.004 \\
\hline & & & $(0.163)$ & & & $(0.134)$ \\
\hline \multicolumn{7}{|l|}{ Interactions with Africa dummy } \\
\hline \multirow[t]{2}{*}{ Ln(Population) } & & -0.027 & 0.024 & & -0.010 & 0.041 \\
\hline & & $(0.048)$ & $(0.054)$ & & $(0.040)$ & $(0.044)$ \\
\hline \multirow[t]{2}{*}{ Ln(Population Density) } & & 0.039 & 0.046 & & 0.010 & 0.041 \\
\hline & & $(0.035)$ & $(0.041)$ & & $(0.029)$ & $(0.034)$ \\
\hline \multirow[t]{2}{*}{ Natural Resources } & & 0.001 & 0.052 & & -0.014 & 0.010 \\
\hline & & $(0.061)$ & $(0.081)$ & & $(0.051)$ & $(0.067)$ \\
\hline \multirow[t]{2}{*}{ Ln(Per Capita Income) } & & -0.013 & 0.109 & & -0.042 & 0.136 \\
\hline & & $(0.065)$ & $(0.136)$ & & $(0.054)$ & $(0.112)$ \\
\hline \multirow[t]{2}{*}{ Population * GDP Per Capita } & & 0.051 & 0.160 & & -0.110 & -0.178 \\
\hline & & $(1.634)$ & $(1.833)$ & & $(1.373)$ & $(1.513)$ \\
\hline \multirow[t]{2}{*}{ Real GDP Growth Rate } & & & 2.120 & & & 1.425 \\
\hline & & & $(1.930)$ & & & $(1.592)$ \\
\hline \multirow[t]{2}{*}{ Inflation Rate } & & & $1.004^{*}$ & & & $0.830^{*}$ \\
\hline & & & $(0.547)$ & & & $(0.452)$ \\
\hline
\end{tabular}




\begin{tabular}{|c|c|c|c|c|c|c|}
\hline Current Account Balance / GDP & & & $\begin{array}{c}-1.773 \\
(1.168)\end{array}$ & & & $\begin{array}{l}-1.477 \\
(0.963)\end{array}$ \\
\hline KKM Index & & & $\begin{array}{l}-0.096 \\
(0.121)\end{array}$ & & & $\begin{array}{l}-0.152 \\
(0.100)\end{array}$ \\
\hline Manufacturing / GDP & & & $\begin{array}{l}-0.776 \\
(0.891)\end{array}$ & & & $\begin{array}{l}-0.916 \\
(0.735)\end{array}$ \\
\hline Secondary/Primary Enrollment & & & $\begin{array}{c}0.418 \\
(0.418)\end{array}$ & & & $\begin{array}{c}0.148 \\
(0.345)\end{array}$ \\
\hline Constant & $\begin{array}{c}0.525^{* * *} \\
(0.073)\end{array}$ & $\begin{array}{c}0.467 * * * \\
(0.091)\end{array}$ & $\begin{array}{c}0.990 * * \\
(0.152)\end{array}$ & $\begin{array}{c}0.294^{* * * *} \\
(0.061)\end{array}$ & $\begin{array}{c}0.248 * * * \\
(0.076)\end{array}$ & $\begin{array}{c}0.640^{* * *} \\
(0.125)\end{array}$ \\
\hline Adjusted R2 & 0.33 & 0.31 & 0.45 & 0.37 & 0.34 & 0.51 \\
\hline Observations & 112 & 112 & 99 & 112 & 112 & 99 \\
\hline F(Population Density = 0 for Africa) & & 6.74 & 4.62 & & 3.07 & 4.27 \\
\hline Corresponding p-value & & 0.011 & 0.035 & & 0.083 & 0.042 \\
\hline F(GDP Growth $=0$ for Africa) & & & 0.10 & & & 0.07 \\
\hline Corresponding p-value & & & 0.758 & & & 0.798 \\
\hline $\mathrm{F}$ (Inflation Rate $=0$ for Africa $)$ & & & 0.04 & & & 0.07 \\
\hline Corresponding p-value & & & 0.848 & & & 0.797 \\
\hline $\mathrm{F}$ (KKM Index= 0 for Africa) & & & 1.50 & & & 0.52 \\
\hline Corresponding p-value & & & 0.224 & & & 0.473 \\
\hline F(CA Balance / GDP = 0 for Africa) & & & 0.04 & & & 0.09 \\
\hline Corresponding p-value & & & 0.837 & & & 0.771 \\
\hline F(Natural Resources $=0$ for Africa) & & & 0.02 & & & 0.06 \\
\hline Corresponding p-value & & & 0.893 & & & 0.802 \\
\hline
\end{tabular}

\section{Notes: $\left({ }^{*} \mathbf{p}<0.1,{ }^{* *} p<0.05,{ }^{* * *} p<0.01\right)$.}


Table 6: Factors that could explain the effect of population density on financial development

(combined sample of low and middle income and African countries, excluding South Africa)

\begin{tabular}{|c|c|c|c|c|c|c|c|c|c|}
\hline & \multicolumn{9}{|c|}{ Dependent Variable: Liquid Liabilities/GDP } \\
\hline & $(1)$ & $(2)$ & (3) & $(4)$ & (5) & (6) & $(7)$ & $(8)$ & (9) \\
\hline Ln(Population density) & $\begin{array}{l}0.096 * * * \\
{[12.083]}\end{array}$ & $\begin{array}{c}0.050 \\
{[1.547]}\end{array}$ & $\begin{array}{c}0.013 \\
{[0.2910]}\end{array}$ & $\begin{array}{c}-0.040^{* * *} \\
{[62.300]}\end{array}$ & $\begin{array}{l}-0.035 \\
{[2.438]}\end{array}$ & & & & \\
\hline Roads / Area & & $\begin{array}{c}0.289 \\
{[1.387]}\end{array}$ & & & & $\begin{array}{l}0.512 * * * \\
{[12.633]}\end{array}$ & & & \\
\hline $\begin{array}{l}\text { \% Population in } \\
\text { Largest City }\end{array}$ & & & $\begin{array}{l}1.141^{* *} \\
{[6.326]}\end{array}$ & & & & $\begin{array}{l}1.222 * * \\
{[6.455]}\end{array}$ & & \\
\hline $\begin{array}{l}\text { Geographic branch } \\
\text { penetration }\end{array}$ & & & & $\begin{array}{l}0.256^{* * * *} \\
{[180.65]}\end{array}$ & & & & $\begin{array}{l}0.215^{* * *} \\
{[29.084]}\end{array}$ & \\
\hline $\begin{array}{l}\text { Demographic branch } \\
\text { penetration }\end{array}$ & & & & & $\begin{array}{c}-0.013^{* *} \\
{[4.264]} \\
\end{array}$ & & & & $\begin{array}{l}-0.009 \\
{[2.245]}\end{array}$ \\
\hline Observations & 91 & 71 & 63 & 73 & 73 & 71 & 63 & 73 & 73 \\
\hline \multirow[t]{3}{*}{ Adjusted R2 } & 0.46 & 0.58 & 0.54 & 0.40 & 0.39 & 0.54 & 0.56 & 0.42 & 0.41 \\
\hline & \multicolumn{9}{|c|}{ Dependent Variable: Private Credit/GDP } \\
\hline & $(1)$ & $(2)$ & (3) & $(4)$ & $(5)$ & $(6)$ & $(7)$ & $(8)$ & (9) \\
\hline Ln(Population density) & $\begin{array}{c}0.078^{* *} \\
{[4.62]}\end{array}$ & $\begin{array}{l}0.051 \\
{[0.40]}\end{array}$ & $\begin{array}{l}0.015 \\
{[0.06]}\end{array}$ & $\begin{array}{l}-0.050 \\
{[0.23]}\end{array}$ & $\begin{array}{l}-0.032 \\
{[0.10]}\end{array}$ & & & & \\
\hline Roads / Area & & $\begin{array}{c}0.171 \\
{[0.18]}\end{array}$ & & & & $\begin{array}{c}0.399 * * \\
{[4.32]}\end{array}$ & & & \\
\hline $\begin{array}{l}\text { \% Population in } \\
\text { Largest City }\end{array}$ & & & $\begin{array}{l}1.044 \\
{[0.80]}\end{array}$ & & & & $\begin{array}{l}1.090 \\
{[0.94]}\end{array}$ & & \\
\hline $\begin{array}{l}\text { Geographic branch } \\
\text { penetration }\end{array}$ & & & & $\begin{array}{c}0.248 \\
{[0.41]}\end{array}$ & & & & $\begin{array}{c}0.183 \\
{[0.26]}\end{array}$ & \\
\hline $\begin{array}{l}\text { Demographic branch } \\
\text { penetration }\end{array}$ & & & & & $\begin{array}{l}-0.012 \\
{[0.17]}\end{array}$ & & & & $\begin{array}{c}-0.011 \\
{[014]} \\
\end{array}$ \\
\hline Observations & 99 & 75 & 63 & 76 & 76 & 75 & 63 & 76 & 76 \\
\hline Adjusted R2 & 0.45 & 0.49 & 0.55 & 0.42 & 0.42 & 0.45 & 0.57 & 0.42 & 0.41 \\
\hline
\end{tabular}

Notes: All models estimated via OLS with White's heteroskedasticity-consistent standard errors. We use the same model specifications as those in Table 7, Columns 3 and 7. F-statistics

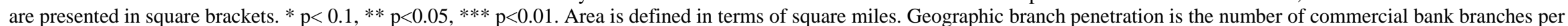

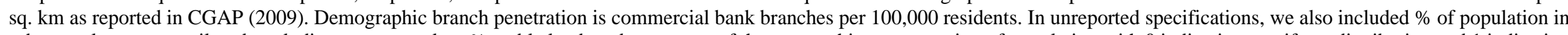

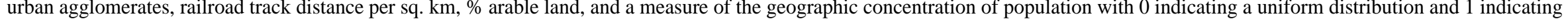
that the entire population is concentrated in a $20 \mathrm{kmx} 20 \mathrm{~km}$ cell (as used in Collier and Hoeffler, 2004). Inclusion of those variables substantially reduced sample size, and none produced consistently significant results for both indicators of financial development, and when population density was excluded from the specification. 


\section{Table 7: Summary Statistics: Firm Sample based on ICS Surveys}

This table presents summary statistics on our firm-level sample (used in regressions in Table 11), based on World Banks' Investment Climate Surveys over the past decade. The surveys were conducted over the period 2002-2006, with the majority of the firms surveyed once. Firm characteristics (all dummy variables) include size (small, medium, and large based on the number of employees), industry (manufacturing, services, and others), exporter status and foreign ownership status. The external finance dummy equals one if a firm has access to loans from domestic or foreign banks, or credit card debts from these institutions, and zero otherwise; we only include firm observations for which data is available on whether the firm has access to all three external financing channels.

\section{Panel A African countries (excluding South Africa)}

\begin{tabular}{ccccc}
\hline & N & Mean & Std. Dev. & Fraction of 0 \\
Firm Size-Small (0 or 1) & 2,591 & 0.46 & 0.50 & -- \\
Firm Size-Medium (0 or 1) & 2,591 & 0.30 & 0.46 & -- \\
Foreign (0 or 1) & 2,591 & 0.25 & 0.43 & - \\
Exporter (0 or 1) & 2,591 & 0.18 & 0.38 & - \\
Manufacturing (0 or 1) & 2,591 & 0.70 & 0.46 & - \\
Services (0 or 1) & 2,591 & 0.17 & 0.37 & - \\
\hline Access to External Finance (0 or 1$)$ & 2,591 & 0.16 & 0.37 & $83.91 \%$ \\
\hline
\end{tabular}

Panel B Other Low- and Middle-income Countries (excluding Africa)

\begin{tabular}{|c|c|c|c|c|}
\hline Firm Size-Small (0 or 1$)$ & 30,525 & 0.34 & 0.47 & -- \\
\hline Firm Size-Medium ( 0 or 1 ) & 30,525 & 0.33 & 0.47 & -- \\
\hline Foreign ( 0 or 1$)$ & 30,525 & 0.13 & 0.33 & -- \\
\hline Exporter ( 0 or 1$)$ & 30,525 & 0.24 & 0.43 & -- \\
\hline Manufacturing ( 0 or 1$)$ & 30,525 & 0.66 & 0.47 & -- \\
\hline Services ( 0 or 1$)$ & 30,525 & 0.27 & 0.44 & -- \\
\hline Access to External Finance ( 0 or 1 ) & 30,525 & 0.26 & 0.44 & $73.75 \%$ \\
\hline
\end{tabular}




\section{Table 8 Regressions for the sample of low and middle income and African countries: Firm-level Results}

This table presents marginal effects from Probit regressions with the dependent variable equal 1 if a firm has access to loans from domestic or foreign banks, or credit card debts from these institutions, and zero otherwise. The surveys were conducted over the period 2002-2006, with the majority of the firms surveyed once. The explanatory variables include firm characteristics and a subset of country-level variables used in Table 7 . We include firms from all the low and middle income countries (including Africa, excluding South Africa), an African dummy variable, and interactions between each of our explanatory variables and the Africa dummy. White's heteroskedasticity-consistent standard errors are clustered at the country-level, and presented in the brackets below coefficients. F-statistics are shown at the bottom of the table.

\begin{tabular}{|c|c|c|c|c|c|}
\hline & (1) & (2) & (3) & (4) & (5) \\
\hline Africa Dummy & $\begin{array}{c}0.011 \\
{[0.104]}\end{array}$ & $\begin{array}{c}0.449 * * \\
{[0.189]}\end{array}$ & $\begin{array}{c}0.230 \\
{[0.169]}\end{array}$ & $\begin{array}{c}-0.061 \\
{[0.111]}\end{array}$ & $\begin{array}{c}0.093 \\
{[0.147]}\end{array}$ \\
\hline Small & $\begin{array}{c}-0.151^{* * *} \\
{[0.023]}\end{array}$ & $\begin{array}{c}-0.144 * * * \\
{[0.015]}\end{array}$ & $\begin{array}{c}-0.140^{* * *} \\
{[0.018]}\end{array}$ & $\begin{array}{c}-0.142 * * * \\
{[0.026]}\end{array}$ & $\begin{array}{c}-0.142 * * * \\
{[0.024]}\end{array}$ \\
\hline Medium & $\begin{array}{c}-0.066^{* * * *} \\
{[0.011]}\end{array}$ & $\begin{array}{c}-0.062 * * * \\
{[0.012]}\end{array}$ & $\begin{array}{c}-0.059 * * * \\
{[0.011]}\end{array}$ & $\begin{array}{c}-0.058 * * * \\
{[0.012]}\end{array}$ & $\begin{array}{c}-0.058 * * * \\
{[0.012]}\end{array}$ \\
\hline Foreign & $\begin{array}{c}-0.046^{* * *} \\
{[0.013]}\end{array}$ & $\begin{array}{c}-0.042 * * * \\
{[0.014]}\end{array}$ & $\begin{array}{c}-0.048^{* * *} \\
{[0.013]}\end{array}$ & $\begin{array}{c}-0.046^{* * *} \\
{[0.013]}\end{array}$ & $\begin{array}{c}-0.046^{* * *} \\
{[0.013]}\end{array}$ \\
\hline Exporter & $\begin{array}{c}0.053 * * * \\
{[0.011]}\end{array}$ & $\begin{array}{c}0.037 * * * \\
{[0.011]}\end{array}$ & $\begin{array}{c}0.059 * * * \\
{[0.011]}\end{array}$ & $\begin{array}{c}0.053^{* * *} \\
{[0.010]}\end{array}$ & $\begin{array}{c}0.053 * * * \\
{[0.011]}\end{array}$ \\
\hline Manufacturing & $\begin{array}{c}0.082 * * * \\
{[0.030]}\end{array}$ & $\begin{array}{l}0.048 * * \\
{[0.024]}\end{array}$ & $\begin{array}{c}0.068 * * * \\
{[0.025]}\end{array}$ & $\begin{array}{c}0.091^{* * *} \\
{[0.030]}\end{array}$ & $\begin{array}{c}0.091 * * * \\
{[0.029]}\end{array}$ \\
\hline Services & $\begin{array}{c}-0.029 \\
{[0.023]}\end{array}$ & $\begin{array}{c}-0.033 \\
{[0.024]}\end{array}$ & $\begin{array}{c}-0.038 \\
{[0.023]}\end{array}$ & $\begin{array}{c}-0.035 \\
{[0.023]}\end{array}$ & $\begin{array}{c}-0.035 \\
{[0.023]}\end{array}$ \\
\hline KKM index & $\begin{array}{l}0.067^{*} \\
{[0.035]}\end{array}$ & $\begin{array}{c}0.032 \\
{[0.028]}\end{array}$ & $\begin{array}{c}0.092^{*} \\
{[0.048]}\end{array}$ & $\begin{array}{c}0.055 \\
{[0.037]}\end{array}$ & $\begin{array}{c}0.056 \\
{[0.037]}\end{array}$ \\
\hline Ln(Per Capita Income) & $\begin{array}{c}-0.007 \\
{[0.032]}\end{array}$ & $\begin{array}{c}-0.029 \\
{[0.032]}\end{array}$ & $\begin{array}{c}0.006 \\
{[0.033]}\end{array}$ & $\begin{array}{c}-0.001 \\
{[0.032]}\end{array}$ & $\begin{array}{c}-0.000 \\
{[0.035]}\end{array}$ \\
\hline Natural Resources & $\begin{array}{c}0.015 \\
{[0.023]}\end{array}$ & $\begin{array}{c}0.019 \\
{[0.018]}\end{array}$ & $\begin{array}{c}0.001 \\
{[0.029]}\end{array}$ & $\begin{array}{c}0.018 \\
{[0.022]}\end{array}$ & $\begin{array}{c}0.018 \\
{[0.022]}\end{array}$ \\
\hline Age of the firm & $\begin{array}{c}-0.001^{* *} \\
{[0.000]}\end{array}$ & $\begin{array}{c}-0.001 * * \\
{[0.000]}\end{array}$ & $\begin{array}{c}-0.001^{* *} \\
{[0.000]}\end{array}$ & $\begin{array}{c}-0.001^{* * *} \\
{[0.000]}\end{array}$ & $\begin{array}{c}-0.001 * * * \\
{[0.000]}\end{array}$ \\
\hline Ln(Population Density) & $\begin{array}{c}0.054 * * * \\
{[0.019]}\end{array}$ & $\begin{array}{c}0.021 \\
{[0.026]}\end{array}$ & $\begin{array}{c}0.045^{* *} \\
{[0.018]}\end{array}$ & $\begin{array}{l}0.060 * * \\
{[0.026]}\end{array}$ & $\begin{array}{c}0.059 * * * \\
{[0.020]}\end{array}$ \\
\hline Roads/Area & & $\begin{array}{l}0.060^{*} \\
{[0.034]}\end{array}$ & & & \\
\hline Foreign Ownership Share & & & $\begin{array}{l}-0.197 * \\
{[0.119]}\end{array}$ & & \\
\hline Number branches per $1000 \mathrm{~km} 2$ & & & & $\begin{array}{c}-0.004 \\
{[0.034]}\end{array}$ & \\
\hline Number branches per 100k adults & & & & & $\begin{array}{c}-0.000 \\
{[0.001]}\end{array}$ \\
\hline Small*Africa & $\begin{array}{c}0.020 \\
{[0.042]}\end{array}$ & $\begin{array}{c}-0.014 \\
{[0.037]}\end{array}$ & $\begin{array}{c}0.008 \\
{[0.045]}\end{array}$ & $\begin{array}{c}-0.047 \\
{[0.037]}\end{array}$ & $\begin{array}{c}-0.022 \\
{[0.041]}\end{array}$ \\
\hline Medium*Africa & $\begin{array}{c}0.069 \\
{[0.043]}\end{array}$ & $\begin{array}{c}0.022 \\
{[0.040]}\end{array}$ & $\begin{array}{c}0.065 \\
{[0.043]}\end{array}$ & $\begin{array}{c}-0.028 \\
{[0.029]}\end{array}$ & $\begin{array}{c}0.000 \\
{[0.033]}\end{array}$ \\
\hline Foreign*Africa & 0.013 & 0.017 & 0.049 & 0.005 & 0.000 \\
\hline
\end{tabular}


Exporter*Africa

Manufacturing*Africa

Services*Africa

KKM index*Africa

Ln(Per Capita Income)*Africa

Natural Resources*Africa

Age of the firm*Africa

Ln(Population Density)*Africa

Roads/Area*Africa

Foreign Ownership Share*Africa

Num branches per $1000 \mathrm{~km} 2 *$ Africa

Num branches per 100K adults*Africa

$\begin{array}{ccccc}{[0.032]} & {[0.035]} & {[0.035]} & {[0.041]} & {[0.040]} \\ 0.019 & 0.034 & 0.002 & -0.037 & -0.012 \\ {[0.031]} & {[0.029]} & {[0.031]} & {[0.033]} & {[0.028]} \\ -0.110^{* * *} & -0.076^{*} & -0.118^{* * *} & -0.097 * * & -0.103^{* *} \\ {[0.034]} & {[0.041]} & {[0.033]} & {[0.045]} & {[0.042]} \\ -0.184^{* * *} & -0.148^{* * *} & -0.179 * * * & -0.157 * * * & -0.180 * * * \\ {[0.021]} & {[0.032]} & {[0.032]} & {[0.033]} & {[0.027]} \\ 0.035 & 0.108 & 0.072 & -0.003 & 0.014 \\ {[0.079]} & {[0.080]} & {[0.085]} & {[0.089]} & {[0.090]} \\ -0.045 & -0.002 & -0.049 & -0.043 & 0.012 \\ {[0.059]} & {[0.073]} & {[0.060]} & {[0.084]} & {[0.074]} \\ -0.035 & -0.451 & 0.279 & 1.439 * * * & 0.725 \\ {[0.484]} & {[0.453]} & {[0.614]} & {[0.476]} & {[0.909]} \\ 0.002 * * * & 0.001 & 0.002 * * & 0.002 * * & 0.002 * * * \\ {[0.001]} & {[0.001]} & {[0.001]} & {[0.001]} & {[0.001]} \\ -0.000 & 0.086^{*} & -0.014 & -0.018 & 0.030 \\ {[0.031]} & {[0.051]} & {[0.027]} & {[0.045]} & {[0.039]} \\ & -0.483^{* *} & & & \\ & {[0.222]} & & & \end{array}$

0.004 [0.013]

\begin{tabular}{|c|c|c|c|c|c|}
\hline Observations & 35,912 & 30,054 & 34,622 & 32,276 & 32,276 \\
\hline Adjusted R square & 0.0874 & 0.0785 & 0.0904 & 0.0921 & 0.0910 \\
\hline test ln_pd+ln_pd*africa chi2 & 4.574 & 5.909 & 2.396 & 1.285 & 7.006 \\
\hline p-value ln_pd & 0.0325 & 0.0151 & 0.122 & 0.257 & 0.00812 \\
\hline test roads_area + roads_area_africa = 0 chi2 & & 3.741 & & & \\
\hline $\mathrm{p}$-value roads & & 0.0531 & & & \\
\hline test fos + fos_africa $=0$ chi 2 & & & 13.51 & & \\
\hline $\mathrm{p}$-value fos & & & 0.000237 & & \\
\hline test geobrpen + geobrpen_africa $=0$ chi2 & & & & 13.54 & \\
\hline p-value geobrpen & & & & 0.000233 & \\
\hline test demobrpen + demobrpen_africa $=0$ chi2 & & & & & 0.0866 \\
\hline pvalue demobrpen & & & & & 0.769 \\
\hline
\end{tabular}




\section{Table 9 Number of Bank Branches by type of District}

This table reports the number of bank branches by type of district: Urban, Rural and Arid and Semi-Arid. This table was constructed based on alternative sources, including phone calls, official websites, banks’ annual reports and government publications.

\begin{tabular}{lcccc}
\hline District & $\mathbf{2 0 0 6}$ & $\mathbf{2 0 0 9}$ & Change & \% Change \\
\hline Urban & 290 & 471 & 181 & 62 \\
Rural & 238 & 398 & 160 & 67 \\
Arid and Semi-Arid & 42 & 89 & 47 & 112 \\
\hline Total & $\mathbf{5 7 0}$ & $\mathbf{9 5 8}$ & $\mathbf{3 8 8}$ & $\mathbf{6 8}$ \\
\hline \hline
\end{tabular}

\section{Table 10 Bank Branches over Time: Commercial Banks in Kenya}

This table reports the number of Kenyan bank branches by bank name and ownership in 2006 and 2009. The table considers only banks with 20 or more bank branches by 2009. This table was constructed based on alternative sources, including phone calls, official websites, banks' annual reports and government publications.

\begin{tabular}{|c|c|c|c|c|}
\hline Local private banks & 2006 & 2009 & Change & $\%$ Change \\
\hline Equity Bank & 44 & 112 & 68 & 155 \\
\hline Co-operative Bank of Kenya Ltd. & 52 & 83 & 31 & 60 \\
\hline Diamond Trust Bank of Kenya Ltd. & 8 & 32 & 24 & 300 \\
\hline Commercial Bank of Africa Ltd. & 19 & 20 & 1 & 5 \\
\hline All local private banks & 247 & 450 & 203 & 82 \\
\hline \multicolumn{5}{|l|}{ Foreign banks } \\
\hline Barclays Bank of Kenya Ltd. & 62 & 119 & 57 & 92 \\
\hline Standard Chartered Bank Kenya Ltd. & 31 & 35 & 4 & 13 \\
\hline K-Rep Bank Ltd. & 22 & 30 & 8 & 36 \\
\hline All foreign banks & 150 & 258 & 108 & 72 \\
\hline \multicolumn{5}{|c|}{ Government and government-influenced banks } \\
\hline Kenya Commercial Bank Ltd. & 117 & 169 & 52 & 44 \\
\hline National Bank of Kenya Ltd. & 33 & 43 & 10 & 30 \\
\hline CFC Stanbic Bank Ltd. & 16 & 35 & 19 & 119 \\
\hline All gov. and gov.-influenced banks & 179 & 262 & 83 & 46 \\
\hline
\end{tabular}




\section{Table 11 Market Participation Major Commercial Banks in Kenya}

This table reports market shares of gross assets, total deposits, total capital, number of deposit accounts and number of loan accounts as at $31^{\text {st }}$ January, 2011. This table was constructed based on alternative sources, including official websites, banks' annual reports and government publications.

\begin{tabular}{lccccc}
\hline & $\begin{array}{c}\text { Gross } \\
\text { Assets }\end{array}$ & $\begin{array}{c}\text { Total } \\
\text { Deposits }\end{array}$ & $\begin{array}{c}\text { Total } \\
\text { Capital }\end{array}$ & $\begin{array}{c}\text { Number of } \\
\text { Deposit Accounts }\end{array}$ & $\begin{array}{c}\text { Number of } \\
\text { Loan Accounts }\end{array}$ \\
\hline Kenya Commercial Bank Ltd & $13.5 \%$ & $13.2 \%$ & $15.4 \%$ & $10.93 \%$ & $19.8 \%$ \\
Barclays Bank of Kenya Ltd & $10.4 \%$ & $9.9 \%$ & $12.2 \%$ & $6.77 \%$ & $14.1 \%$ \\
Co-operative Bank & $9.0 \%$ & $9.8 \%$ & $7.5 \%$ & $12.26 \%$ & $12.0 \%$ \\
Standard Chartered Bank Ltd & $8.2 \%$ & $8.3 \%$ & $7.6 \%$ & $0.92 \%$ & $1.5 \%$ \\
Equity Bank Ltd. & $8.0 \%$ & $7.8 \%$ & $10.7 \%$ & $47.39 \%$ & $33.8 \%$ \\
CfC Stanbic Bank Ltd & $5.9 \%$ & $6.2 \%$ & $3.8 \%$ & $0.47 \%$ & $1.8 \%$ \\
\hline \hline
\end{tabular}

Table 12 Use of Bank Services in Kenya

This table reports the percentage of people having a bank account and a loan from a bank in Kenya. It also reports the presence of Equity across districts. This table was constructed based on FinAccess 2006 and 2009 surveys and alternative sources, including phone calls, official websites, banks' annual reports and government publications.

\begin{tabular}{lcc}
\hline Variable & $\mathbf{2 0 0 6}$ & $\mathbf{2 0 0 9}$ \\
\hline Bank account & $14.20 \%$ & $22.70 \%$ \\
Bank Loan & $2.90 \%$ & $4.40 \%$ \\
Equity Bank presence & $48 \%$ & $87 \%$ \\
\hline \hline
\end{tabular}




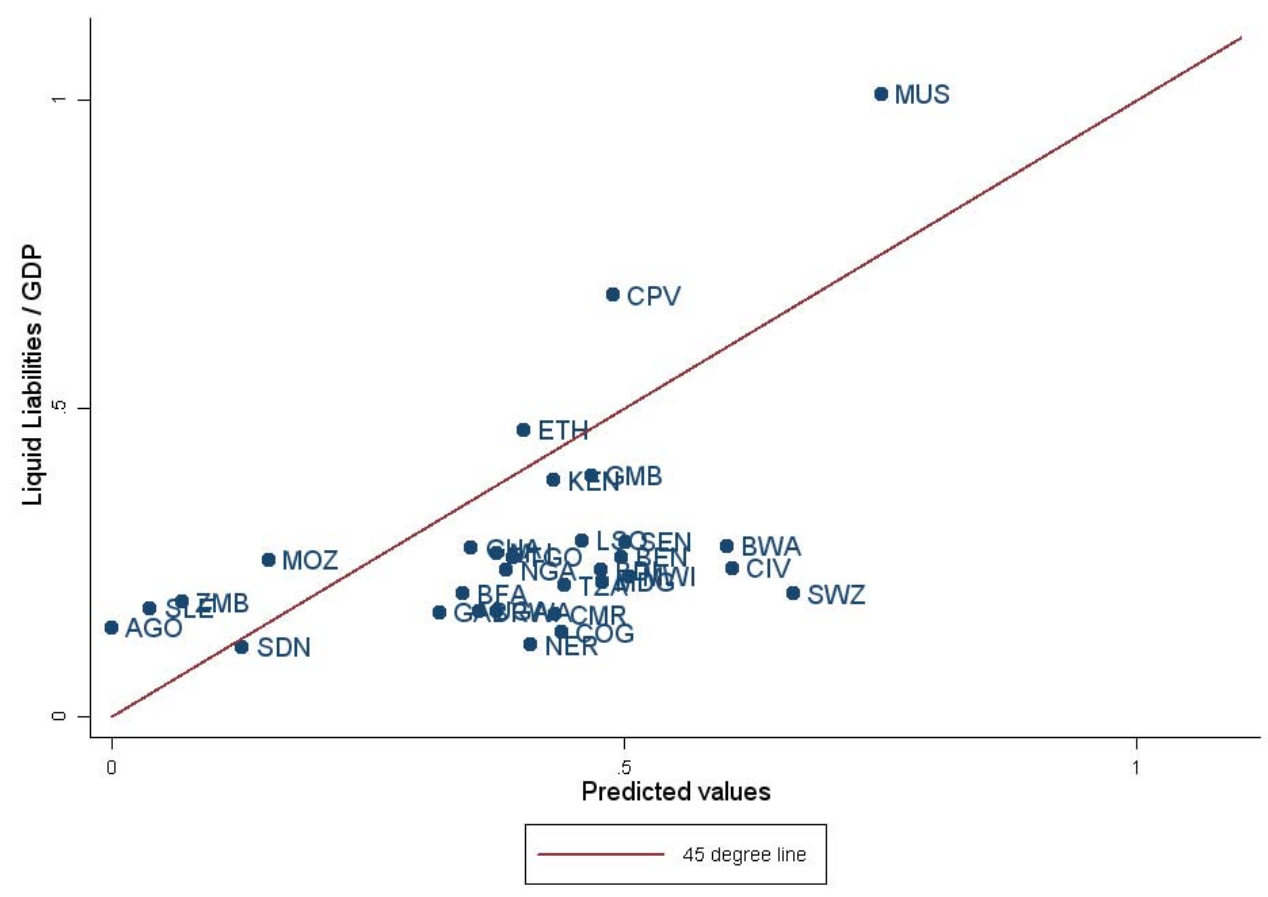

Figure 1: Liquid liabilities / GDP in African countries, actual vs. predicted values (Notes: Based on the specification in Table 3, Column 4; negative predicted values are replaced by zero).

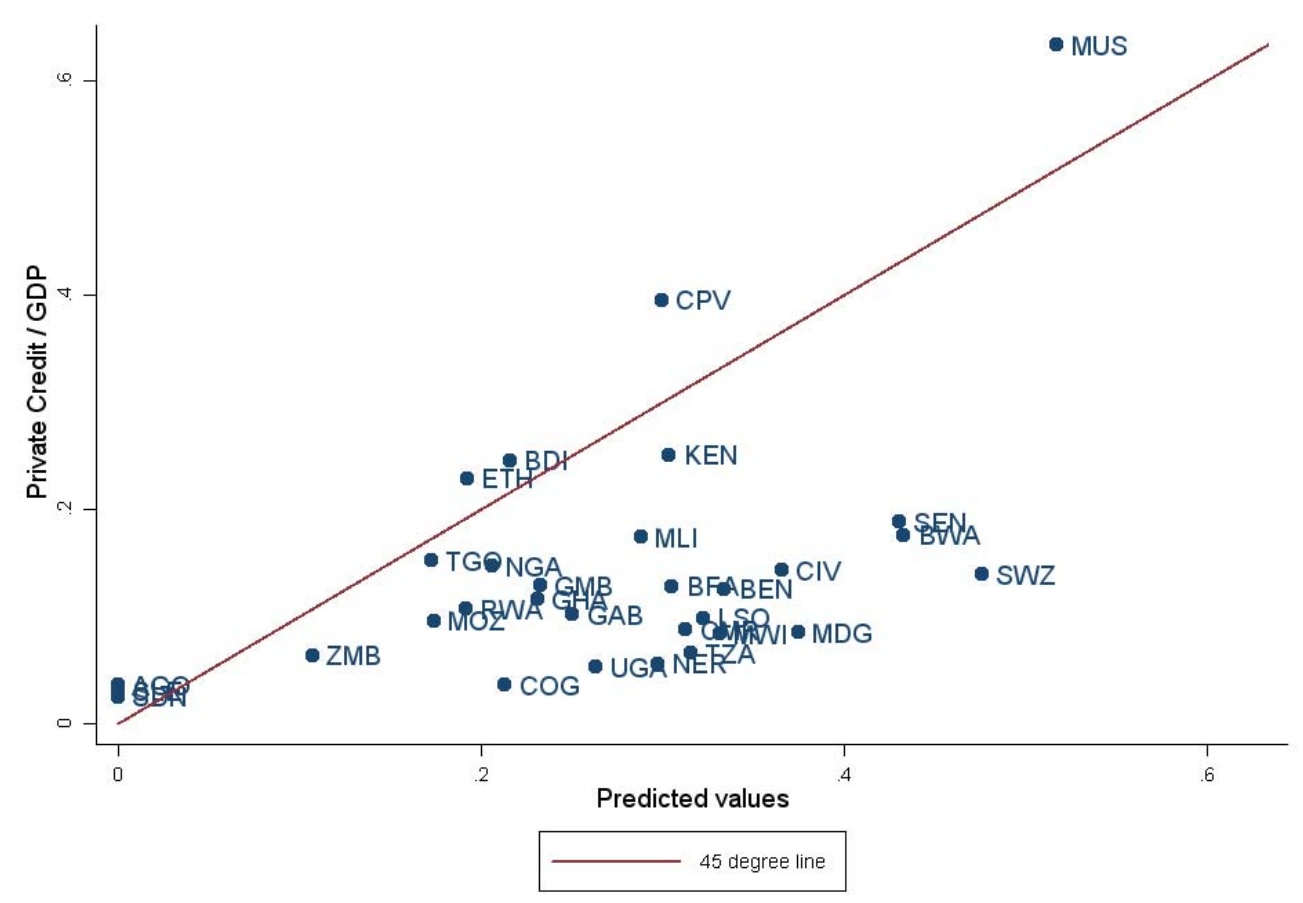

Figure 2: Private credit / GDP in African countries, actual vs. predicted values

(Notes: Based on the specification in Table 3, Column 8; negative predicted values are replaced by zero.) 


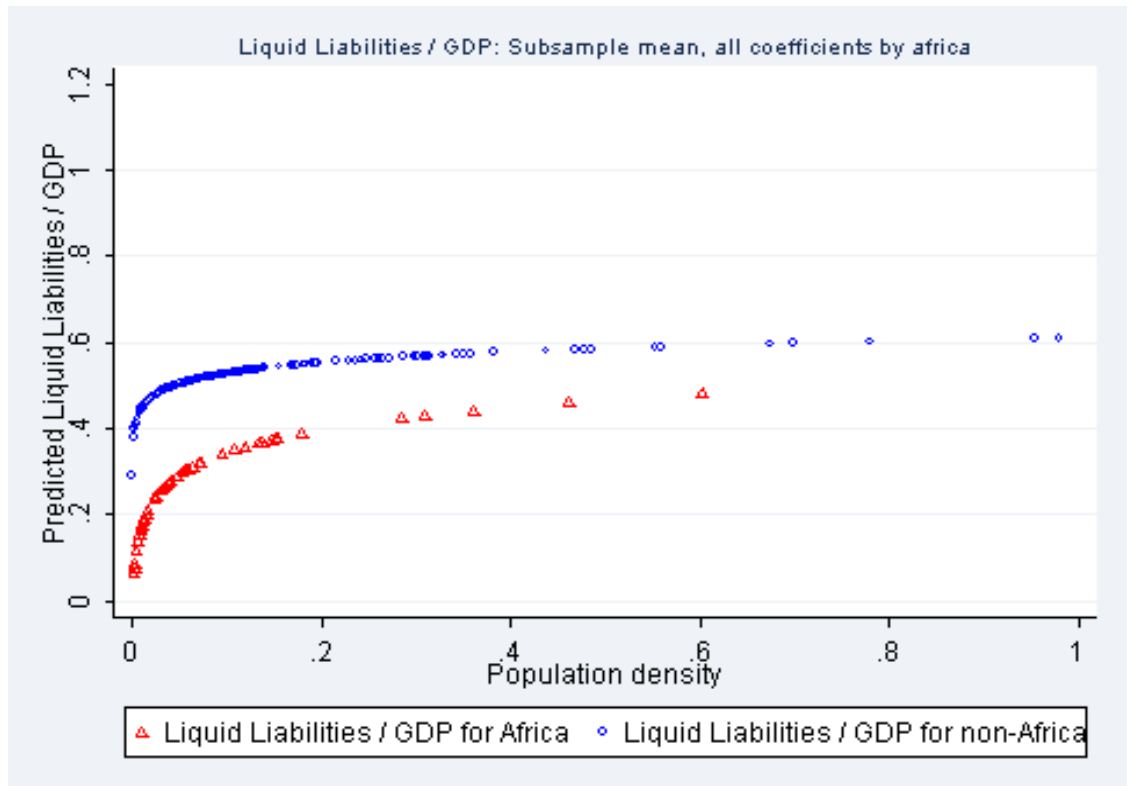

Figure 3: Relationship between population density and liquid liabilities/GDP

Notes: Plots are for the typical African and non-African developing country based on Table 5 . Specifically, the vertical axis plots predicted values from Model 2 in Table 5. For all variables other than population density, we use the mean value for the subsample (either Africa or other developing countries) multiplied by the appropriate coefficient for that subsample. For population density, we run through the range of possible values and multiply by the appropriate coefficient for each subsample to generate the curvature.

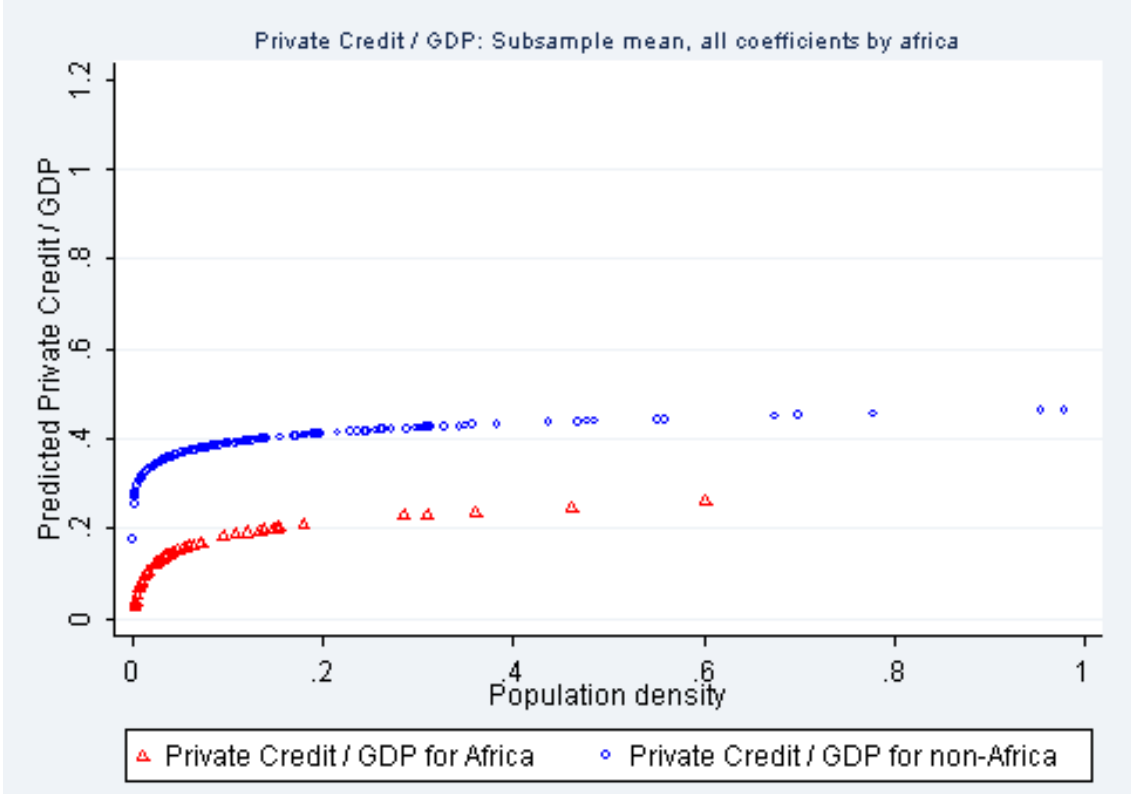

Figure 4 Relationship between population density and private credit/GDP

Notes: The vertical axis plots predicted values from Model 5 in Table 5. For all variables other than population density, we use the mean value for the subsample (either Africa or other developing countries) multiplied by the appropriate coefficient for that subsample. For population density, we run through the range of possible values and multiply by the appropriate coefficient for each subsample to generate the curvature. 


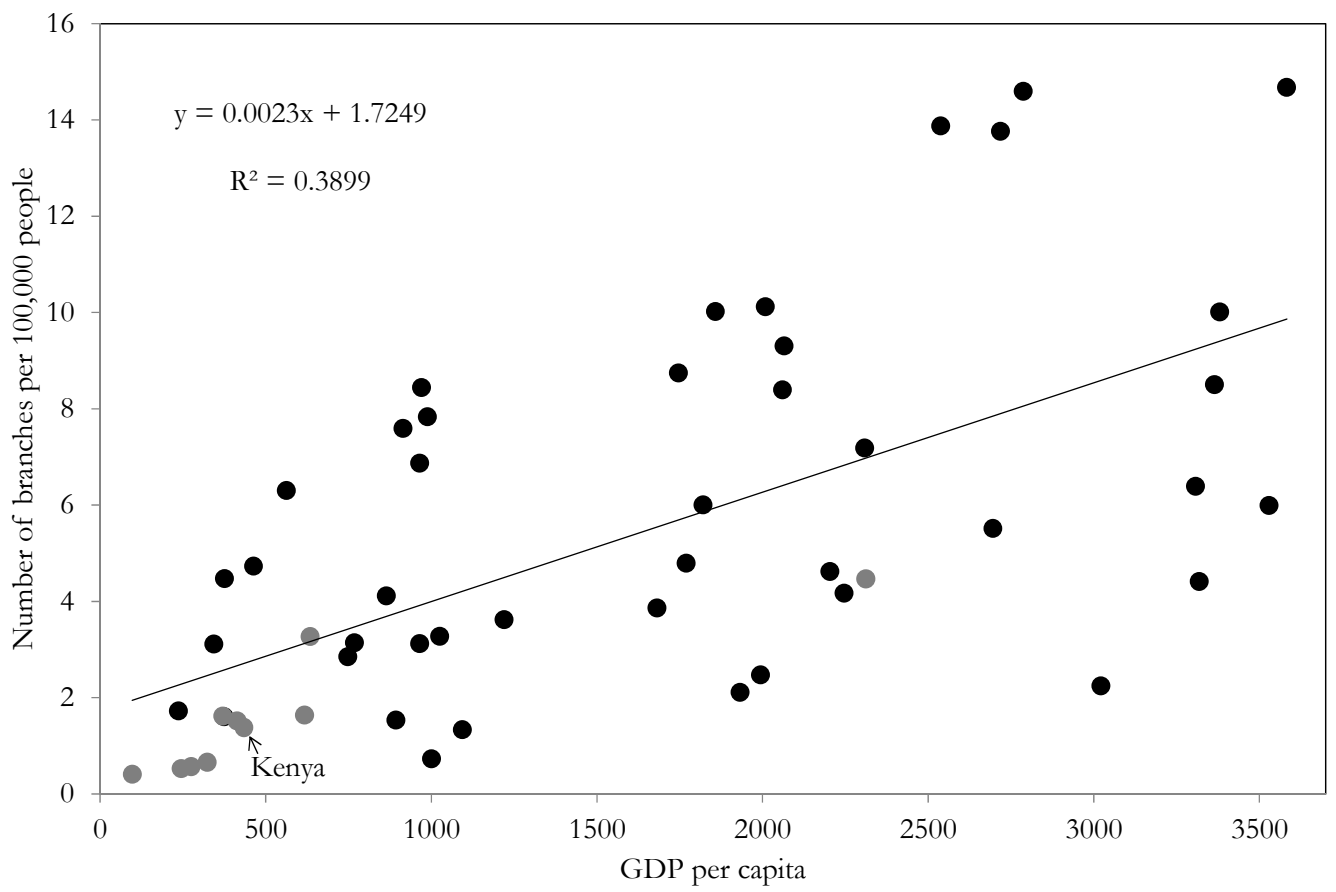

Figure 5. Demographic bank penetration and GDP per capita. This figure shows the relationship between GDP per capita and the number of bank branches per 100,000 people across low income economies in 2003/2004. The sample considers countries with a GDP per capita below 4,000USD. The grey dots correspond to Sub-Saharan African countries. The black dots correspond to the rest of the countries. The data source is Beck, Demirguc-Kunt, and Martinez Peria (2007).

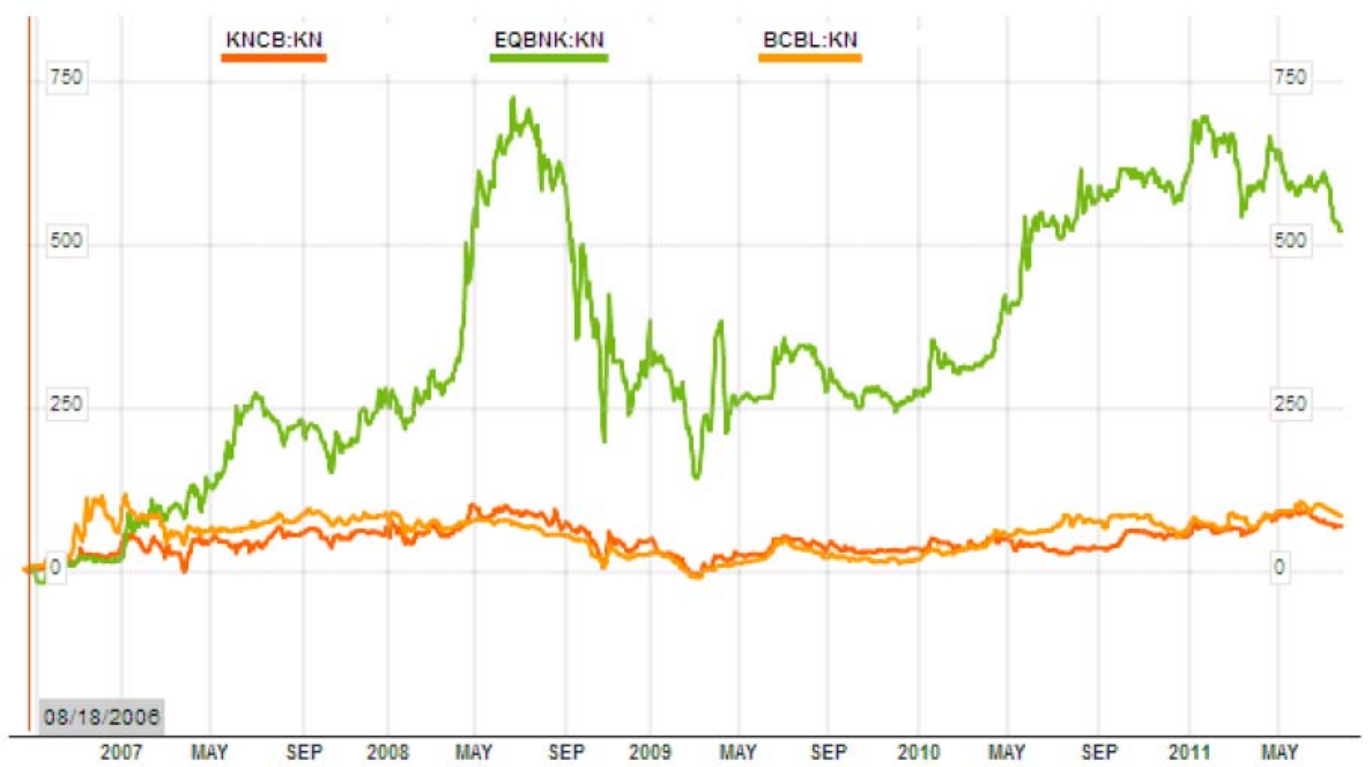

Figure 6. Stock market performance. This figure shows the stock market performance of Kenya Commercial Bank (KNCB), Equity Bank (EQBNK) and Barclays Bank of Kenya (BCBL) since August $18^{\text {th }}$, 2006. The data source is interactive chart from Bloomberg (http://www.bloomberg.com). 

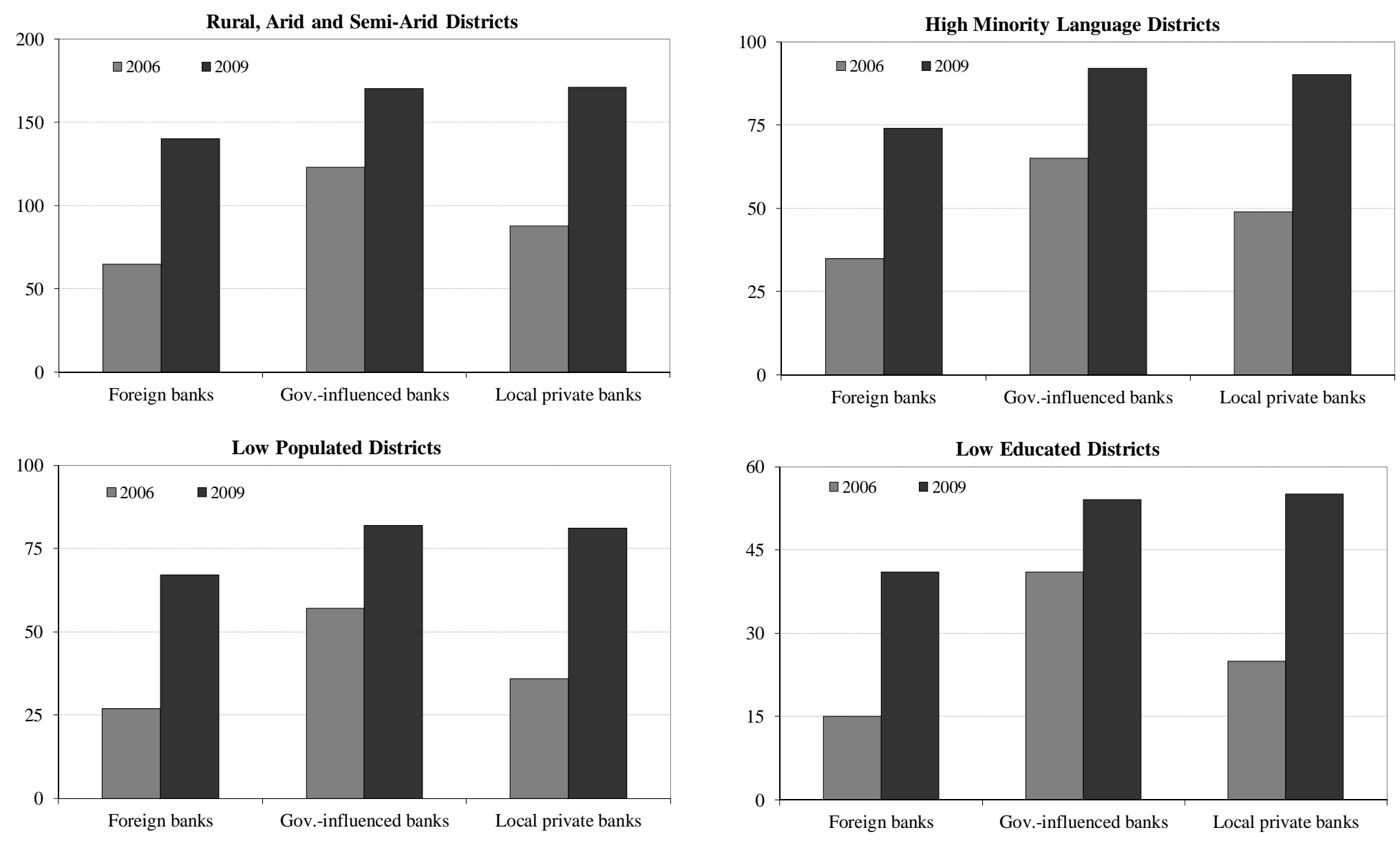

Figure 7. Bank penetration in vulnerable districts. This figure shows the number of bank branches according to different ownership structures: Foreign banks, Government banks, and Domestic private banks. Rural, Arid and Semi-Arid Districts exclude Nairobi and Mombasa. High minority language districts are the ones where the share of the population speaking a minority language is larger than the median. Low populated districts are the ones where the density population is smaller than the median. Low educated districts are the ones where the share of the population with secondary or tertiary education is smaller than the median. 

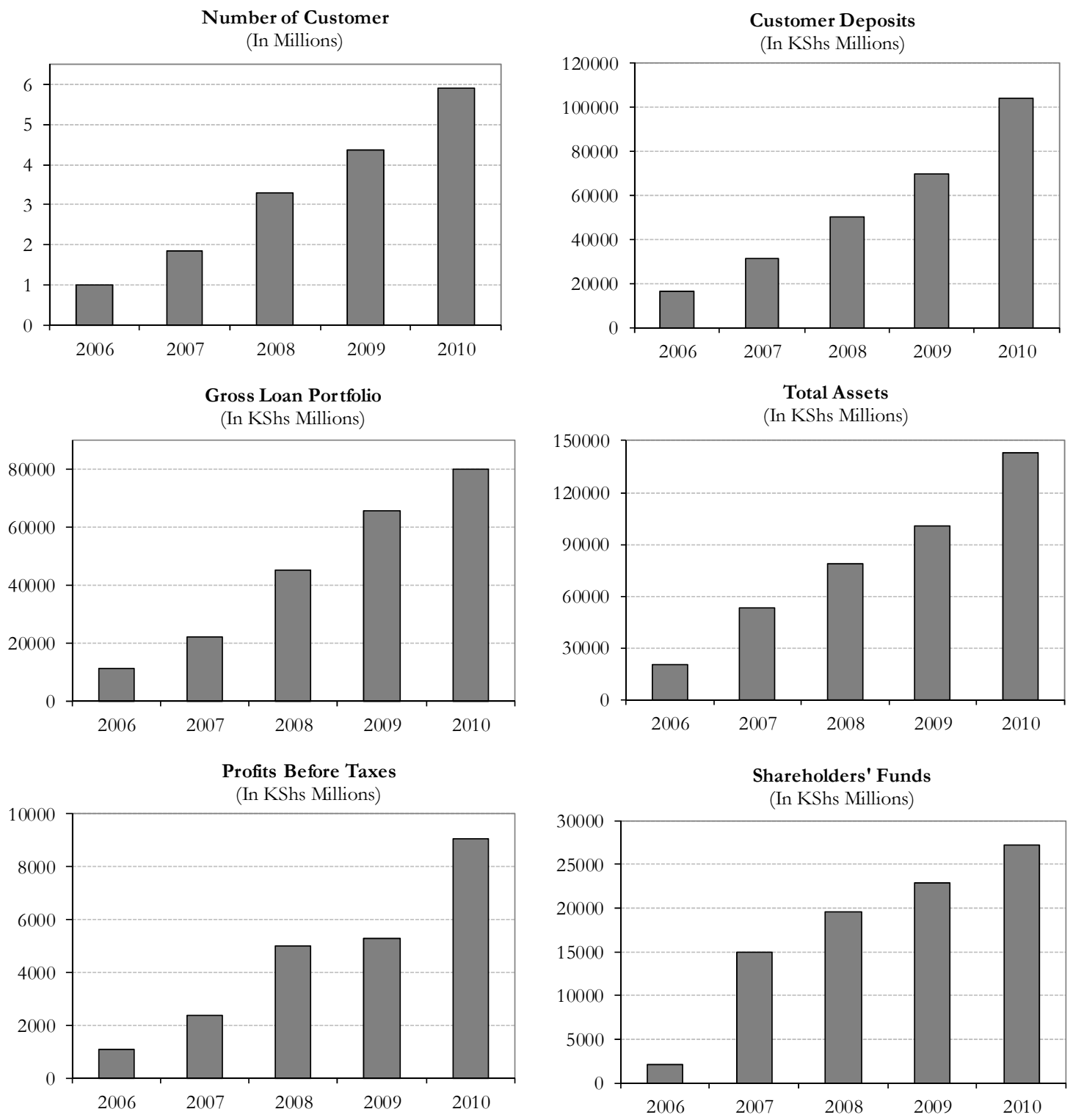

Figure 8. Equity Bank's performance indicators. This figure shows the evolution of the number of customers, deposits, gross loan portfolio, total assets, profits before taxes, and shareholders' funds over the period 2006-2010. The data source is the Equity Bank’s Annual Report and Financial Statements 2010. 